Article

\title{
DEM-Based Analysis of Interactions between Tectonics and Landscapes in the Ore Mountains and Eger Rift (East Germany and NW Czech Republic)
}

\author{
Louis Andreani ${ }^{1,2}, *$, Klaus P. Stanek ${ }^{2}$, Richard Gloaguen ${ }^{1}$, Ottomar Krentz ${ }^{3}$ \\ and Leomaris Domínguez-González ${ }^{2}$ \\ ${ }^{1}$ Department of Exploration, Helmholtz Institute Freiberg for Resource Technology, \\ Halsbrücker Str. 34, 09599 Freiberg, Germany; E-Mail: r.gloaguen@ @zdr.de \\ ${ }^{2}$ Institut für Geologie, TU Bergakademie Freiberg, Bernhard-von-Cotta Str. 2, 09599 Freiberg, \\ Germany; E-Mails: stanek@geo.tu-freiberg.de (K.P.S.); leomargeo@ yahoo.es (L.D.-G.) \\ ${ }^{3}$ Sächsisches Landesamt für Umwelt, Landwirtschaft und Geologie, Halsbrücker Str. 31A, \\ 09599 Freiberg, Germany; E-Mail: Ottomar.Krentz@smul.sachsen.de \\ * Author to whom correspondence should be addressed; E-Mail: 1.andreani @hzdr.de; \\ Tel.: +49-351-260-4426.
}

Received: 26 April 2014; in revised form: 9 August 2014 / Accepted: 11 August 2014 / Published: 26 August 2014

\begin{abstract}
Tectonics modify the base-level of rivers and result in the progressive erosion of landscapes. We propose here a new method to classify landscapes according to their erosional stages. This method is based on the combination of two DEM-based geomorphic indices: the hypsometric integral, which highlights elevated surfaces, and surface roughness, which increases with the topographic elevation and the incision by the drainage network. The combination of these two indices allows one to produce a map of erosional discontinuities that can be easily compared with the known structural framework. In addition, this method can be easily implemented (e.g., in MATLAB) and provides a quick way to analyze regional-scale landscapes. We propose here an example of a region where this approach becomes extremely valuable: the Ore Mountains and adjacent regions. The lack of young stratigraphic markers prevents a detailed analysis of recent fault activity. However, discontinuities in mapped geomorphic indices coupled to the analysis of river longitudinal profiles suggest a tight relationship between erosional discontinuities and main tectonic lineaments.
\end{abstract}


Keywords: Eger Rift; Ore Mountains (Erzgebirge); geomorphic indices; tectonics; Germany (Saxony); Czech Republic

\section{Introduction}

Landscapes affected by recent or active tectonics result from a competition between vertical uplift and erosional processes (e.g., [1,2]). Phenomena, such as topographic uplift, subsidence or climatically-induced sea-level changes, modify the base-level of rivers and result in the progressive erosion or rejuvenation of pre-existing topographic features through time (e.g., [3,4]). Geomorphic indices are commonly used to detect the response of landscapes to recent deformation processes ([2,5] and the references therein). During the last decade, an increasing number of algorithms and toolboxes were developed in order to extract these indices from digital elevation models and to analyze landscapes (e.g., [6-10]).

Common approaches in tectonic geomorphology rely on the analyses of drainage networks (e.g., [11-16]) and topographic surfaces (e.g., [17-20]). River profile analyses proved to be useful in detecting active structures, delineating spatial patterns in rock uplift rates and, in some cases, estimating the amount of uplift or incision for different segments of a river (e.g., [21-23]). Hypsometric curves are commonly used to classify basins between different erosional (and thus evolutionary) stages (e.g., [24-26]). These methods are highly efficient for small areas, but are still difficult to apply to a regional scale, as the amount of data to extract (especially from a drainage network) is extremely important. DEM-based computation of parameters, such as surface roughness or hypsometric integral, provides a fast way to analyze regional-scale interactions between landscapes and tectonics. However, results are difficult to interpret, as they point to broad domains that do not always coincide with mapped tectonic features. Both drainage network and surface analyses have been successfully used to evaluate active tectonics in areas subjected to high deformation rates (e.g., [16,27-29]). However, only a few works were done in intra-plate settings or in areas with low deformation rates (e.g., [12,30-33]). A major concern is that in slowly deformed areas, erosion processes may counterbalance or overcome the effects of active tectonics on present-day topography, thus questioning the suitability of geomorphic indices.

Our aim is to test the sensitivity of DEM-based geomorphic analyses in the slowly deformed regions surrounding the Eger Rift in Central Europe (location in Figure 1) and to provide new information regarding the recent (Late Miocene to present) tectonic evolution of this area. Although the Eger Rift and the Ore Mountains were intensively explored geologically and geophysically (e.g., [34,35]), only a few studies investigated recent or active tectonics (e.g., [36-38]) as the lack of young stratigraphic markers prevents a detailed analysis of recent fault activity. During most of the twentieth century, the Bohemian Massif, as well as Central Europe were regarded as a stable intra-continental region. Indeed, present-day tectonic rates are low in Central Europe ( $<2 \mathrm{~mm} / \mathrm{yr})$ [39,40]. However, earthquake swarms [36,38,41-45], $\mathrm{CO}_{2}$-emanation [46,47] and geological studies [37] provide evidence for active magmatism and ongoing tectonic activity along the NW part of the Bohemian Massif. From a geomorphic point of view the 
Plio-Quaternary uplift of the Bohemian Massif resulted in the increase of incision rates for the main rivers and, thus, in the entrenchment of the drainage network [48,49].

Figure 1. Simplified geological map of Central Europe. The black rectangle indicates the studied area, which contains the Eger Rift and Ore Mountains.

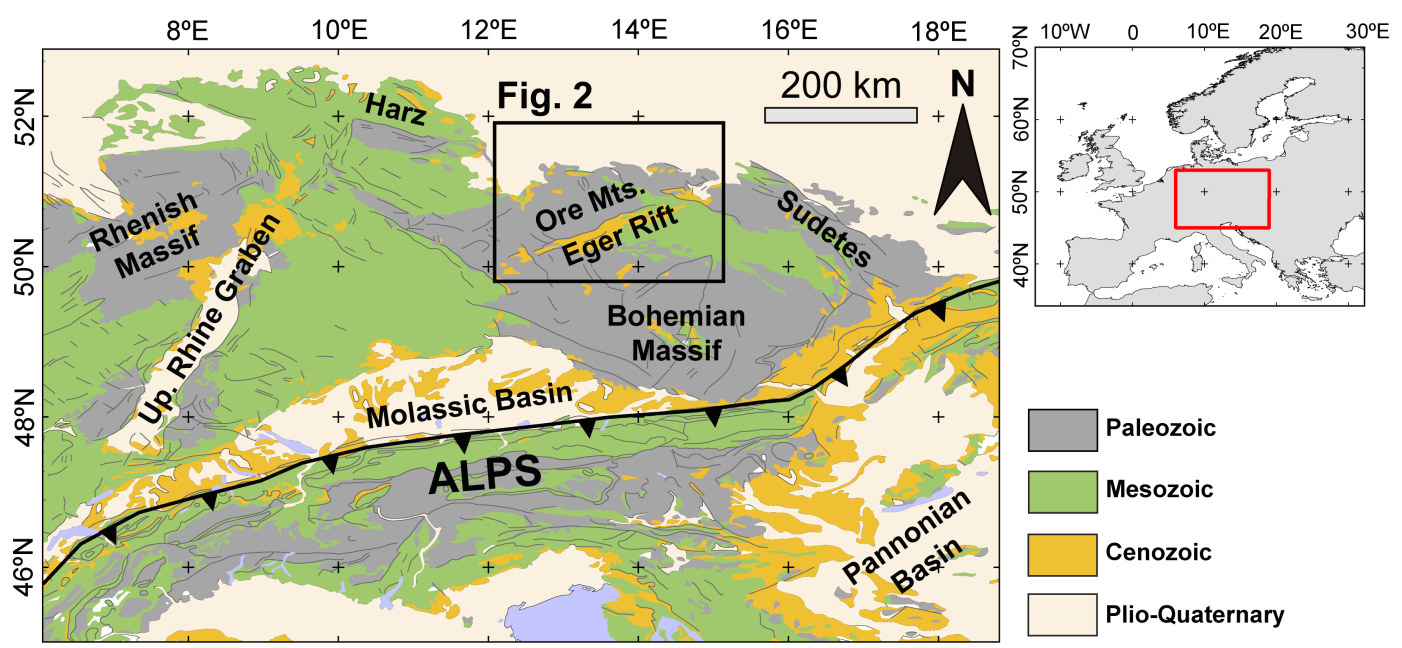

In order to analyze the regional-scale effects of tectonics on topography, we combine topographic profiles and geomorphic indices extracted from DEM data. We propose to combine the hypsometric integral and the surface roughness in order to produce a map of erosional discontinuities and elevated topographic surfaces, which can be easily compared with the known structural framework. We also analyzed the drainage network in order to estimate base-level changes and incisions. In spite of low deformation rates, our geomorphic analyses suggest that the topography of areas surrounding the Eger Rift is tightly controlled by tectonics.

\section{Geological Setting}

The Eger Rift is the eastern part of the European Cenozoic Rift System, which transects the Variscan basement in the foreland of the Alps [50-52]. The Eger Rift lies on a Variscan suture zone between the Saxothuringian and Teplá-Barrandian terranes [44,53] and is underlain by the metamorphic complexes of Teplá and the Ore Mountains, as well as the Early Paleozoic Lusatian granodiorite massif (Figure 2). The Eger Rift consists of several NE-trending Paleogene to Neogene sedimentary basins and volcanic fields (the largest are the Doupov volcanic complex and the Bohemian Uplands) which are limited to the north by the Krušné Hory Fault and to the south by the Ohře (Eger) and Litoměřice fault zones. To the west, the influence of Tertiary tectonics reaches into northern Bavaria (Cheb Basin), to the east of the Eger Rift (Zittau and Radomiercyze basins) and ends obviously at the Inner Lusatian Fault Zone (Figure 2).

The western and central segments of the rift are well expressed and consist in the 40-km long and $10 \mathrm{~km}$-wide Sokolov Depression and in the $80 \mathrm{~km}$-long and up to $30 \mathrm{~km}$-wide Most Basin (Figure 2). Here, the topographic scarps are well defined, cross-cutting the high-grade metamorphic and post-kinematic igneous rocks of the Ore Mountains metamorphic complex in the north and the Cretaceous sediments of the Bohemian Basin in the south [54-56]. However, the topographic scarps of the Eger Rift are poorly defined east of the Elbe Fault Zone. The kinematics of NW-trending faults separating the central and 
eastern segments are the object of ongoing studies. In the west, the Mariánské-Lázně Fault and the Plešna Fault represent an active fault zone that indicates an uplift and sinistral displacement of the central segment of the Eger Rift [37,57,58].

Figure 2. Simplified geology and structures of the Eger Rift and Ore Mountains regions, compiled from the geological map at 1:400,000 for Saxony [55] and from the geological map at 1:500,000 for the Czech Republic [56]. This map and the following maps are projected using the Gauss-Krüger Zone 4 coordinate system (EPSG-European Petroleum Survey Group—code: 31468$)$.

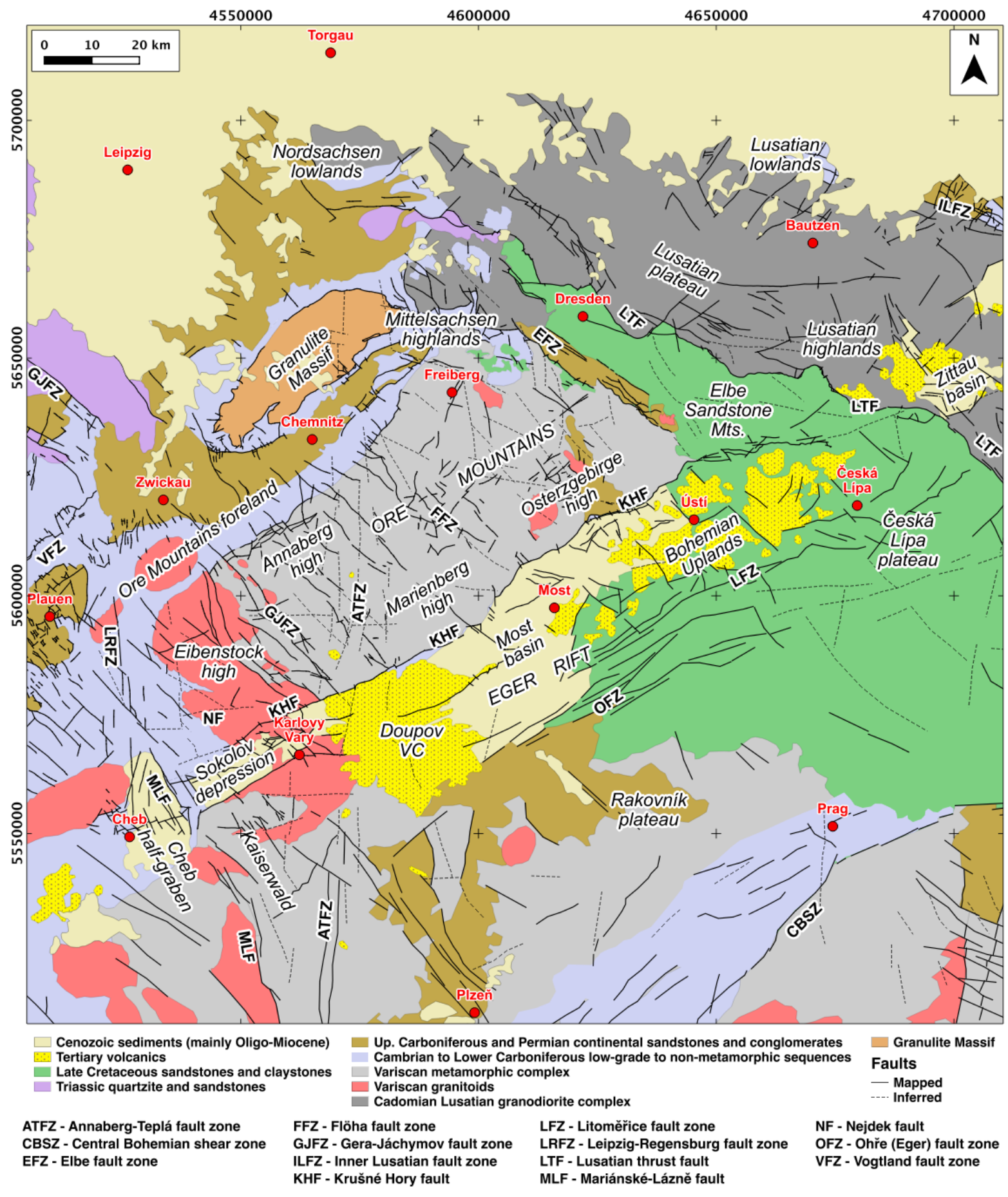


Figure 3. Seismicity of the Eger Rift and Ore Mountains regions [45,55].

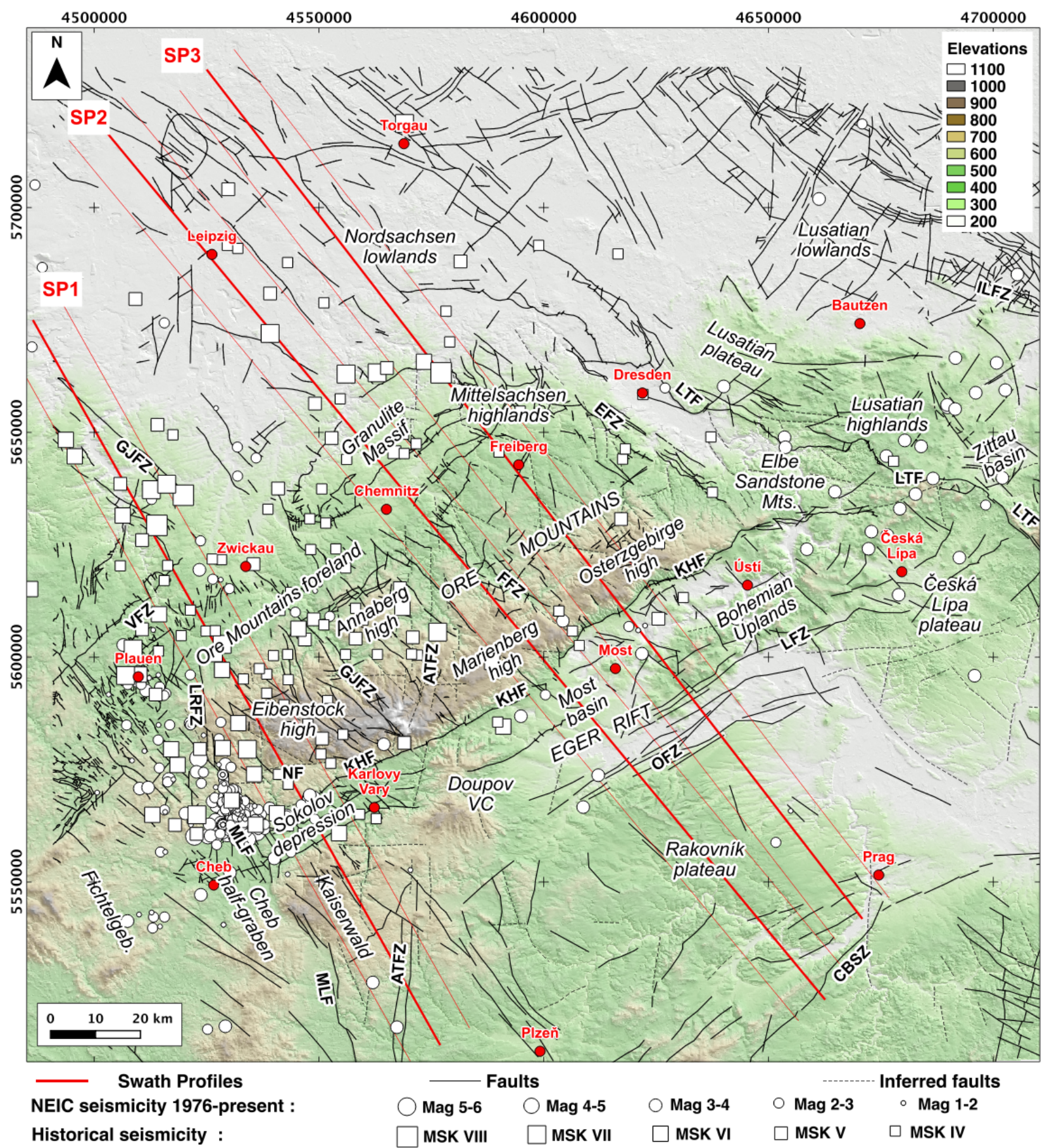

The onset of extension in the Eger Graben is associated with a Late Eocene volcanic pulse [59-61] and is followed by a major subsidence phase [62]. Up to $500 \mathrm{~m}$ of lacustrine and fluvial clastic deposits accumulated in the Eger Depression during the Early Miocene's main extensional period [63]. Volcanic activity decreased during the middle Miocene (16 to $12 \mathrm{Ma}$ ) and intensified again during the late Miocene and Pliocene (11.4 to 3.95 Ma) [60,61]. It locally lasted until 0.11 Ma [60,61]. Magnetostratigraphic and palaeobotanical data suggest that the syn-rift deposition in Eger Rift basins ended during the early Miocene [64]. The post-rift evolution of the Eger Rift is associated with a NW- to NNW-trending compression [65,66]. This compression resulted in the post-early Miocene uplift and tilting of the Ore Mountains' metamorphic complex [52,67]. The Ore Mountains' tilted block is delimited by the Krušné 
Hory Fault to the south, by the Elbe Fault Zone to the east and by the Leipzig-Regensburg Fault Zone to the west (Figure 2). In addition, the Ore Mountains are intersected by regional N- and NW-trending lineaments, such as the Flöha and Gera-Jáchymov fault zones [55]. These NW-trending regional fault zones are suggested to be Mesozoic normal faults, reactivated by tertiary tectonics $[67,68]$.

Little is known about the timing of the uplift in the Ore Mountains. Evidence of post-rift uplift along the Krušné Hory Fault are mainly given by outcrops of Lower Oligocene Sediments preserved below volcanic flows [69] and Lower Miocene sediments with paleoflora found on top of the Hradiště hill near Černovic [34]. These sediments rest on kaolinised basement rocks and represent the uppermost part of the basin-fill of the Most Basin. They have been uplifted at an elevation of $570 \mathrm{~m}$ above sea level. The authors that described these outcrops concluded that the main uplift of the Ore Mountains could not be older than Pliocene [34]. Evidence for ongoing tectonic and magmatic activities along the Mariánské-Lázně Fault and Vogtland region (western tip of the Ore Mountains) come from earthquake swarms [36,38,41-44], $\mathrm{CO}_{2}$-emanation [46,47] and geological studies [37]. Seismological data (Figure 3) suggest that earthquake swarms are mainly triggered along a conjugate set of NNW-trending left-lateral and NW-trending right-lateral faults [38,43]. The stress field inverted from earthquake focal mechanisms indicates a NW compression and an NE extension, which is consistent with the predicted state of stress in Central Europe [38,39,43,65,66].

\section{Methods and Tools}

\subsection{Swath Topographic Profiles}

Swath topographic profiles condense elevation data of a complex landscape into a single profile (e.g., [70-73]). Topography is extracted from a rectangular swath rather than a simple line, as in conventional profiles. Elevations data are then projected onto a vertical plane parallel to the long axis of the swath rectangle, and statistical parameters (usually the maximum, minimum and mean elevations) are calculated. The curve for maximum elevations corresponds to the ridgelines and helps to identify topographic features, such as Paleo-surfaces. The curve for minimum elevations corresponds to the valley floors. A quick estimate of the incision is given by the arithmetic difference between the maximum and minimum elevations.

Swath topographic profiles were extracted from 3 arc-seconds SRTM data (Consultative Group on International Agricultural Research, [74]) using a MATLAB script. The swath width was fixed to $15 \mathrm{~km}$. This value is large enough to contain both elevated surfaces and major rivers and small enough to avoid topographic features that are too oblique with respect to the swath axis. Elevation data were sampled using 175 parallel profiles separated by $\sim 90 \mathrm{~m}$. Elevations along each individual profile were also sampled using a 1-pixel ( $\sim 90 \mathrm{~m})$ interval.

\subsection{Surface Analyses}

We classified landscapes according to their state of dynamic equilibrium using the combination of the hypsometric integral, which efficiently highlights elevated and flat surfaces, and the surface roughness, which substantially increases with incision. The hypsometric integral (Figure 4) shows the distribution of 
landmass volume remaining beneath or above a basal reference plane [24,25]. Pike and Wilson [17] show that the hypsometric integral can be calculated for a given area by using Equation (1):

$$
H I=\frac{h_{\text {mean }}-h_{\min }}{h_{\max }-h_{\min }}
$$

with $h_{\text {mean }}, h_{\min }$ and $h_{\max }$ being the mean, minimum and maximum elevations of the analyzed area. The surface roughness (Figure 4) is given by Equation (2):

$$
S R=\frac{T S}{F S}
$$

with $T S$ and $F S$ being the areas of the analyzed topographic surface and the corresponding flat and horizontal surface $[9,18,19]$. The ratio value is close to 1 for flat areas and increases rapidly as the real surface becomes irregular. We calculated hypsometric integral and surface roughness using TecDEM, a MATLAB-based software allowing the extraction of geomorphologic parameters from digital elevation models [9]. We used 90-m resolution SRTM data from CIAT [74]. Each pixel of the output raster represents the hypsometric integral and surface roughness values for a 100-pixel $(\sim 9 \mathrm{~km})$ moving window (Figure 4).

Figure 4. Surface indices. Calculation of the hypsometric integral and surface roughness within a moving window of size (i). Both values are assigned to the central pixel $(x, y)$ of the output raster.

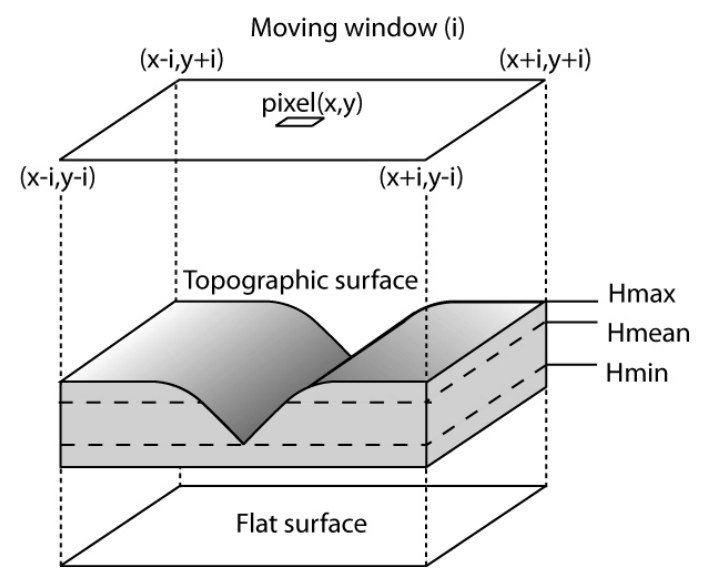

$$
\begin{aligned}
& \text { Hypsometric integral }=\frac{H \text { mean }-\mathrm{Hmin}}{\mathrm{Hmax}-\mathrm{Hmin}} \\
& \text { Surface roughness }=\frac{\text { Topographic surface }}{\text { Flat surface }}
\end{aligned}
$$

The hypsometric integral is sensitive to elevated surfaces and poorly eroded scarps $[20,24,27,75]$, while surface roughness increases with the dissection by the drainage network. In order to map simultaneously preserved and eroded portions of an elevated landscape, we implemented a new index (referred to as the "surface index", SI) in the TecDEM toolbox. This index combines elevations, hypsometric integral and surface roughness using Equation (3):

$$
S I=\left(\frac{H I-H I_{\min }}{H I_{\max }-H I_{\min }}\right) \times\left(\frac{h-h_{\min }}{h_{\max }-h_{\min }}\right)-\left(\frac{S R-S R_{\min }}{S R_{\max }-S R_{\min }}\right)
$$

$\mathrm{HI}, \mathrm{h}$ and SR represent the values of hypsometry, elevation and surface roughness for each pixel converted into ratios using the maximum and minimum values for each raster datum. Positive SI values are mainly associated with poorly incised surfaces (which are characterized by a high hypsometric integral and low 
surface roughness). Negative SI values will essentially reflect areas with high surface roughness values (mainly dissected landscapes), but will also be sensitive to elevation factors.

\subsection{River Networks and Longitudinal Profiles}

We extracted the drainage network from a 20-m resolution DGM for Saxony and a 30-m resolution ASTER GDEM for surrounding areas (Figure 5). The extraction was done using TecDEM [8] by calculating flow directions and contributing area for each pixels using the D8 algorithm [76,77]. Streams were identified using a minimum contributing area of $1 \mathrm{~km}^{2}$ and organized hierarchically using Strahler order [78].

Figure 5. Drainage network of the Eger Rift and Ore Mountains regions extracted using TecDEM [8] and organized hierarchically using Strahler order [78].
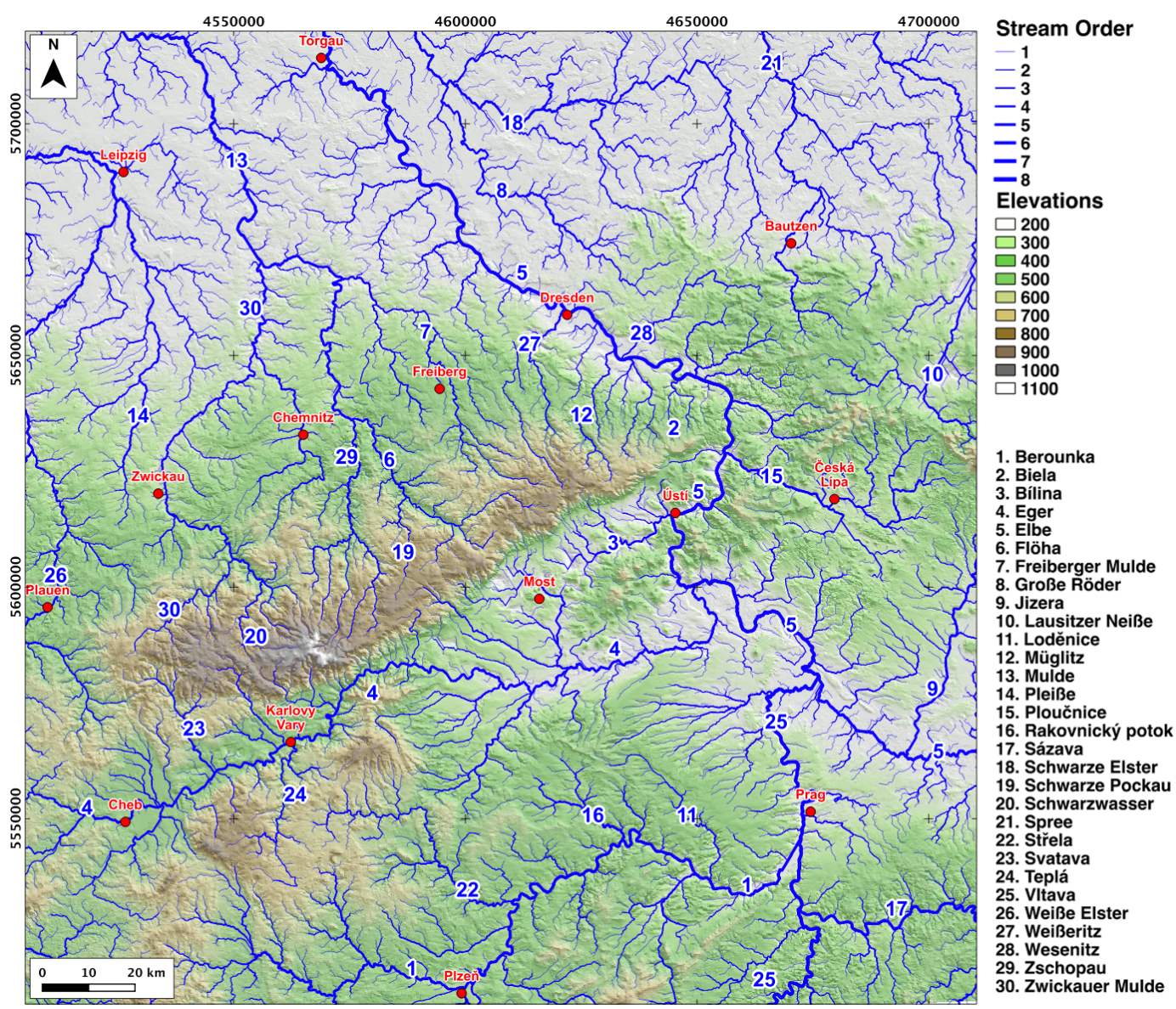

Deviations from the typical concave-up shape of stream longitudinal profiles, such as knickpoints or convex segments, indicate a disequilibrium state resulting from tectonic, base-level or lithological perturbations [12,28,30,79,80]. The normalized steepness index $\left(k_{s n}\right.$, Figure 6B) is widely used to investigate tectonically-induced perturbations in river longitudinal profiles, as it shows a direct proportionality with uplift rates (e.g., $[22,23,79,81])$. The relationships between slope and catchment area which define the equilibrium state channel gradient are given by Equations (4) and (5) [22,79,82]:

$$
S=k_{s} \times A^{-\theta}
$$


with:

$$
k_{s}=\left(\frac{U}{K}\right)^{\frac{1}{n}}
$$

where $S$ is the local channel slope, $\theta$ is the channel concavity, $k_{s}$ is the steepness index, $A$ is the upstream drainage area, $U$ is the rock uplift rate and $K$ is the dimensional coefficient of erosion. As suggested by Wobus et al. ([22], and the references therein) a normalized steepness index $k_{s n}$ is used, since $k_{s}$ and $\theta$ are strongly correlated. We analyzed river longitudinal profiles using TecDEM [8]. Normalized steepness indices were computed from Equation (4) by regressing concave segments in logarithmic plots of the slope against the catchment area and by using a reference concavity $\theta_{\text {ref }}=0.45$ (Figure 6B; [22,79]). Prominent knickpoints or convex anomalies (Figure 6B) can be observed directly on river longitudinal profiles. However, logarithmic plots of slope against catchment area allow a more detailed analysis, as minor anomalies in the gradient of rivers can be easily detected. For each longitudinal profile, we selected and regressed several segments delimited by changes in the gradient of the river. We then plotted on a map regressed segments and their assigned $k_{s n}$ values.

Figure 6. Analysis of river profiles. (A) Schematic river profiles corresponding to steady-state and transient states; (B) calculation of the normalized steepness index for a river profile and corresponding drainage area. Slope of $\log$ (Slope) vs. $\log$ (Area) scaling is the concavity index $\theta$; the y-intercept is the steepness index $k_{s}$. In this example, the normalized steepness index $k_{s n}$ is calculated using a reference concavity of 0.45 . (C) Reconstruction of the upper base-level of a transient river profile using linear regressions on subsets of the $\log$ (Slope) $v s$. $\log$ (Distance) plot (bootstrapping method).

(A) Steady-state profile
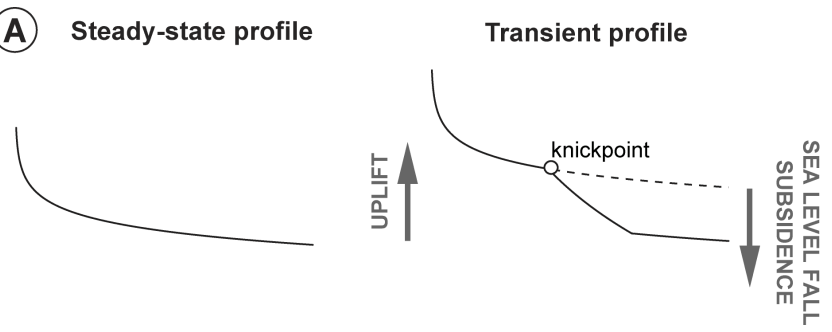

(B) Normalized steepness index
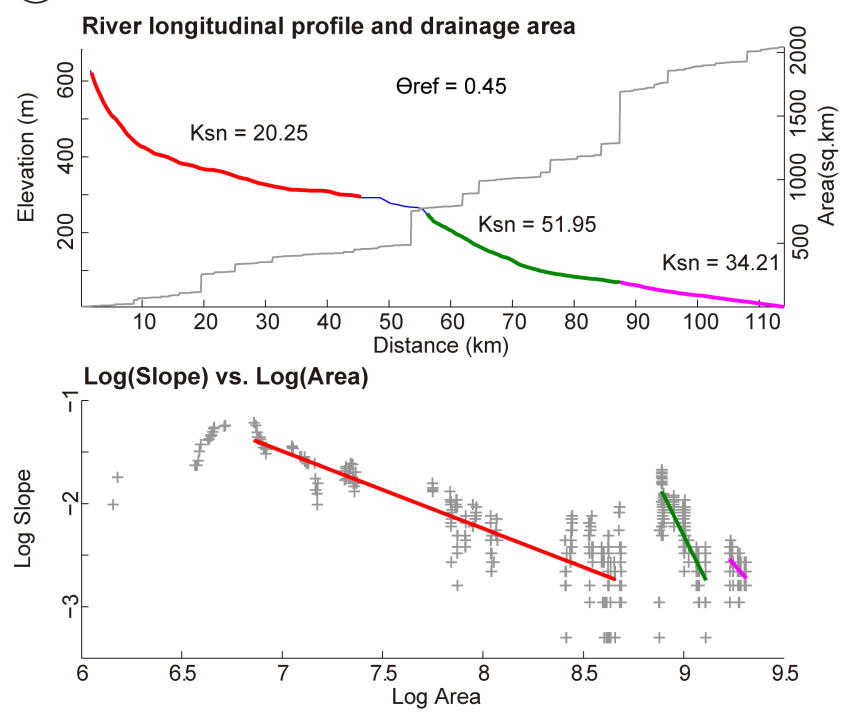

(C) Base-level reconstruction
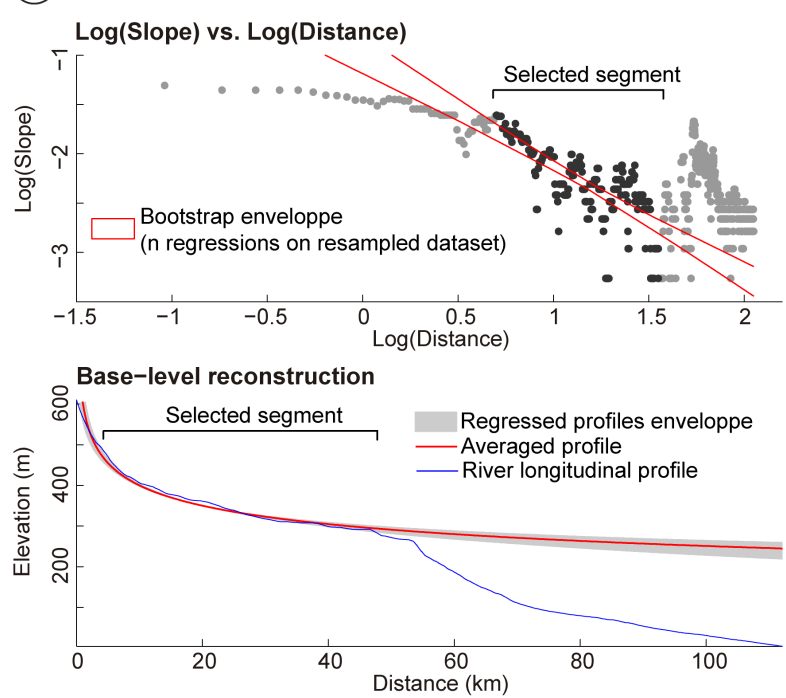

Difference between reconstructed profile and actual profile

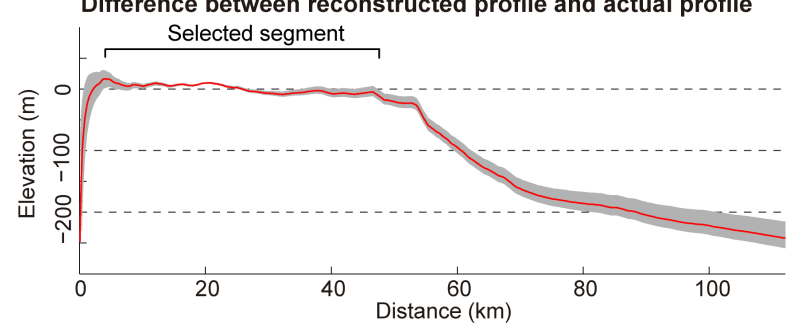


In some cases, the upstream portion located above prominent knickpoints is associated with an upper-relict landscape. The reconstruction of the original stream profile downstream of the confluence with its major trunk rivers provides an estimate for the amount of subsequent incision (e.g., [83-85]). To reconstruct the original stream profile, we used the power law between slope and distance defined by Equation (6) [86]:

$$
S=i \times D^{j}
$$

$S$ is the local channel slope and $D$ is the distance from the drainage divide. Parameters $i$ and $j$ are obtained by regressing the upper segment of the stream profile in a logarithmic plot of slope against distance (Figure 6C). The application of this method to river profiles extracted from DEM is greatly limited by the resolution and quality of the DEM. To overcome this issue, we estimate parameters $i$ and $j$ using bootstrapping (Figure 6C). We subsetted the original dataset using 75\% randomly-selected points, and we performed a linear regression on each subset. This method allows us to assess the quality of the base-level reconstruction. It also provides a reliable estimate of the incision by comparing the reconstructed and the actual profiles.

\section{Results}

\subsection{Swath Topographic Profiles}

NNW-trending swath Profiles 1 to 3 (Figure 7) allow one to compare the along-strike variations of the main tectonic and topographic features across the Eger Graben and Ore Mountains. In each profile, the Eger Graben is well defined by topographic scarps located along the Ohře Fault Zone to the south and the Krušné Hory Fault to the north. The difference in elevation between the northern and southern rims of the Graben is well marked in the east (almost $500 \mathrm{~m}$ in Profile 3 ) but decreases westward ( $200 \mathrm{~m}$ in Profile 2 and less than $100 \mathrm{~m}$ in Profile 1). The eastward widening of the Eger Graben is also clearly expressed in topographic profiles. The Graben floor is heterogeneous. In Profile 1, it is concave, and the Eger River is clearly entrenched, as indicated by the curve of the maximum topography; while in Profile 2, it is flat and slightly tilted to the south. In Profile 3, the Graben is hidden by the Bohemian Uplands Volcanic Field.

The southern rim of the Eger Graben consists in elevated surfaces (Rakovník Plateau and Kaiserwald Massif), which extend up to $50 \mathrm{~km}$ from the Ohře Fault Zone and is limited to the southeast by the Central Bohemian Shear Zone. The Rakovník Plateau appears sub-horizontal in Profile 3 and slightly tilted towards the southeast in Profile 2. Its mean elevation remains relatively constant $(\sim 300 \mathrm{~m} \mathrm{NW}$ of Prague to $\sim 500$ m north of Plzeň). The Kaiservald Massif appears to be tilted along both the southern border of the Eger Graben (Profile 3) and the Mariánské-Lázně Fault, as the highest elevations ( 900 m) are found at the junction between these two structures. In all profiles, the local incision (green curves in Figure 7) related to the tributaries of the Berounka and Vltava rivers is relatively constant (between 100 and $250 \mathrm{~m}$ ). However, we note a westward increase of the local incision along the Ohře Fault Zone (up to $400 \mathrm{~m}$ in the Kaiserwald Massif).

The Ore Mountains display significant along-strike variations. In topographic profiles, they appear as a block tilted toward the northwest. The SE flank of the range is marked by a sharp topographic scarp associated with the Krušné Hory Fault in Profiles 2 and 3. In Profile 1, the southern flank of the 
Ore Mountains is complicated by a topographic high separated from the rest of the Ore Mountains by a secondary fault ("Nejdek Fault" in Profile 1). All profiles display recognizable surfaces on top of the Ore Mountains (Osterzgebirge, Marienberg and Eibenstock topographic highs). The NW part of the Ore Mountains varies strongly from East to West. The easternmost section (Profile 3 in Figure 7) displays a gentle, slightly concave and continuous surface extending up to $80 \mathrm{~km}$ from the Krušné Hory Fault. The connection with the Nordsachsen lowlands to the north is barely marked. In the central area (Profile 2 in Figure 7), the tilted flank of the Ore Mountains display an almost regular gradient interrupted by a topographic flat. In the westernmost section (Profile 1 in Figure 7), the NW flank of the Ore Mountains display a more concave shape, which connects to a well-defined topographic surface located at the front of the western Ore Mountains (noted "foreland surface" in Figure 7). This surface appears slightly elevated with respect to the Nordsachsen lowlands.

Figure 7. Topographic swath profiles across the Eger Rift and Ore Mountains. See the locations in Figure 3. Swath widths are $15 \mathrm{~km}$. CBSZ, Central Bohemian Shear Zone, KHF, Krušné Hory Fault; NF, Nejdek Fault; OFZ, Ohře (Eger) Fault Zone.

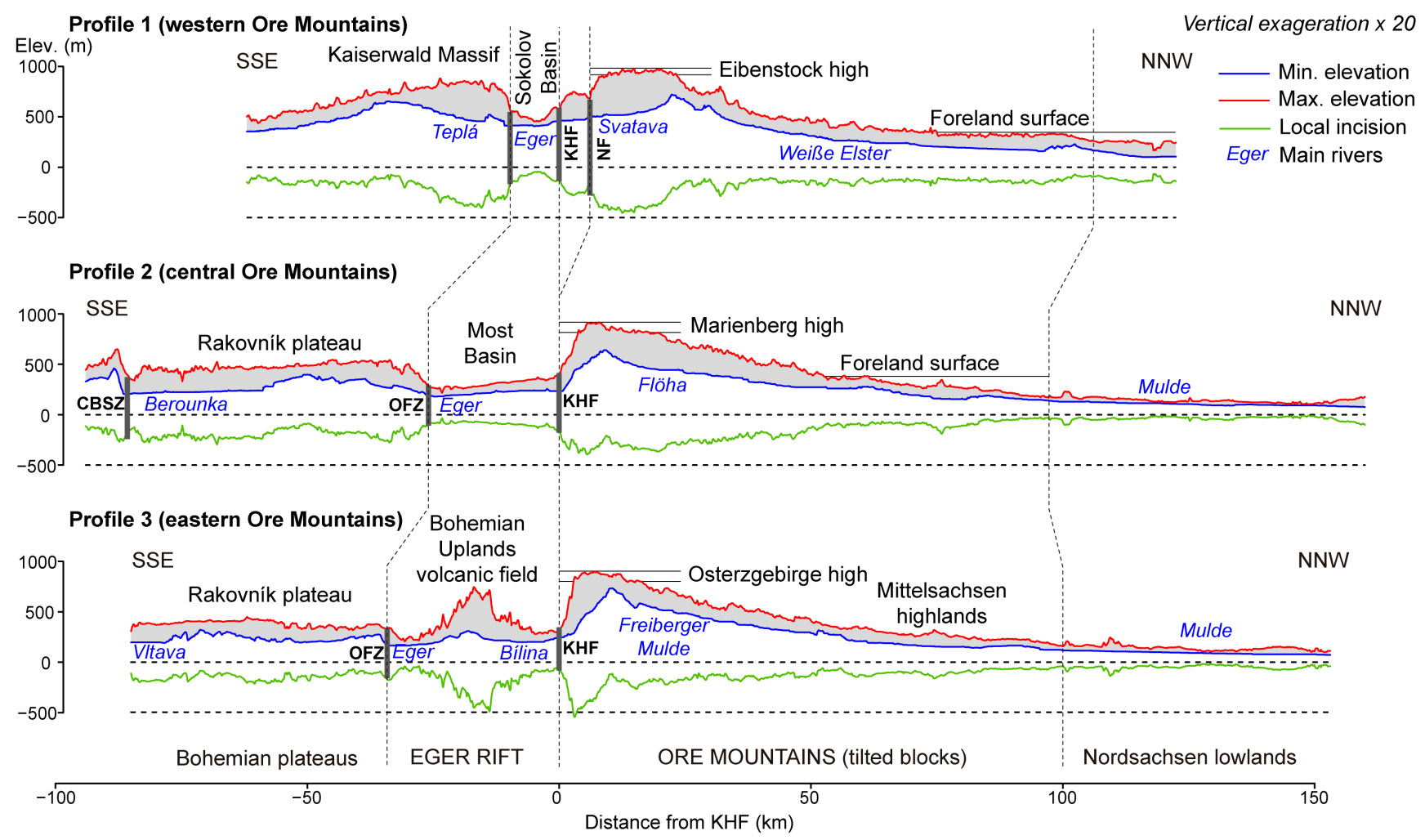

Our swath topographic profiles also suggest significant changes in the local incision by the drainage network. In most of the Ore Mountains, the drainage divide is located $10 \mathrm{~km}$ (Profiles 2 and 3) to $20 \mathrm{~km}$ (Profile 1) away from the Krušné Hory Fault. Differences between the maximum and minimum curves (local incision, green curves in Figure 7) suggest higher incisions (up to $500 \mathrm{~m}$ ) for watersheds located along the SE flank of the Ore Mountains. Local incisions for rivers located along the NW tilted flank of the Ore Mountains vary significantly. The highest incisions are found along the Flöha River, while the Freiberger Mulde and the Weiße Elster show moderate incisions (100 to $150 \mathrm{~m}$ ). 
Figure 8. Surface roughness calculated using a 100-pixel moving window. Values increase with topographic elevation and incision by the drainage network. See Figure 2 for the abbreviations.

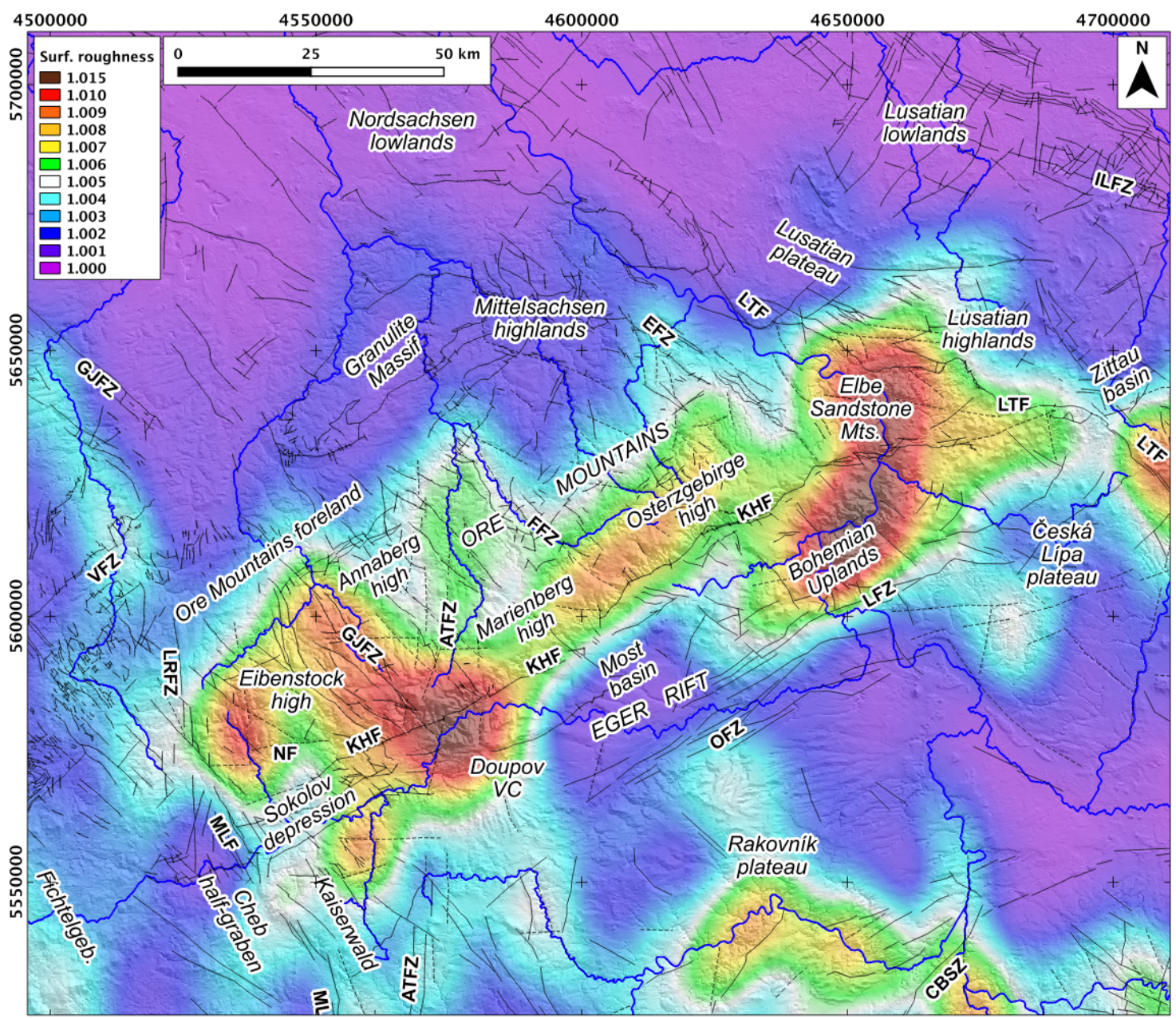

\subsection{Surface Indices}

Surface roughness values (Figure 8 and Table 1) vary between one and 1.015. The lowest values $(<1.001)$ correspond to flat areas with low local incisions, which are also observed in swath topographic profiles (Figure 7). These areas are the gentle hills located north of the Ore Mountains (Nordsachsen and Lusatian lowlands), the Cheb and Most depressions, and the areas located east of the Rakovník Plateau and along the upper segment of the Elbe River. Areas with moderate elevations $(<600 \mathrm{~m})$ mainly display low or intermediate values (1.001 to 1.005). Swath topographic profiles in correspondence with the main rivers (Weiße Elster, Mulde and upper part of the Berounka) show local incisions between 50 and $150 \mathrm{~m}$. However, the lower part of the Berounka River shows higher surface roughness values, as the local incision is higher $(\sim 200 \mathrm{~m})$. The highest surface roughness values $(>1.005)$ are mainly found along the Eger Rift and Ore Mountains. Peak values associated with the entrenchment of the Teplá and Eger rivers are found south and east of the Sokolov Depression. The Bohemian Uplands and the Elbe Sandstone Mountains also display higher surface roughness values, due to the entrenchment of the Elbe River and its tributaries. In the Ore Mountains, the highest values are found around the Eibenstock High and are associated with the catchments of the Schwarzwasser and Svatava rivers. In the central and 
eastern part of the Ore Mountains, we note higher surface roughness values for the areas located south of the main drainage divide. This is related to the combined effect of the topographic scarp along the Krušné Hory Fault and the incisions by the drainage network. North of the drainage divide, we note intermediate values (1.005 to 1.006) along the Flöha and Zschopau rivers and lower values for most of the catchment of the Freiberger Mulde. These differences are probably related to differences in local incision, as indicated by swath profiles.

Figure 9. Hypsometric integral calculated using a 100-pixel moving window. Values above 0.5 highlight elevated surfaces. See Figure 2 for abbreviations.

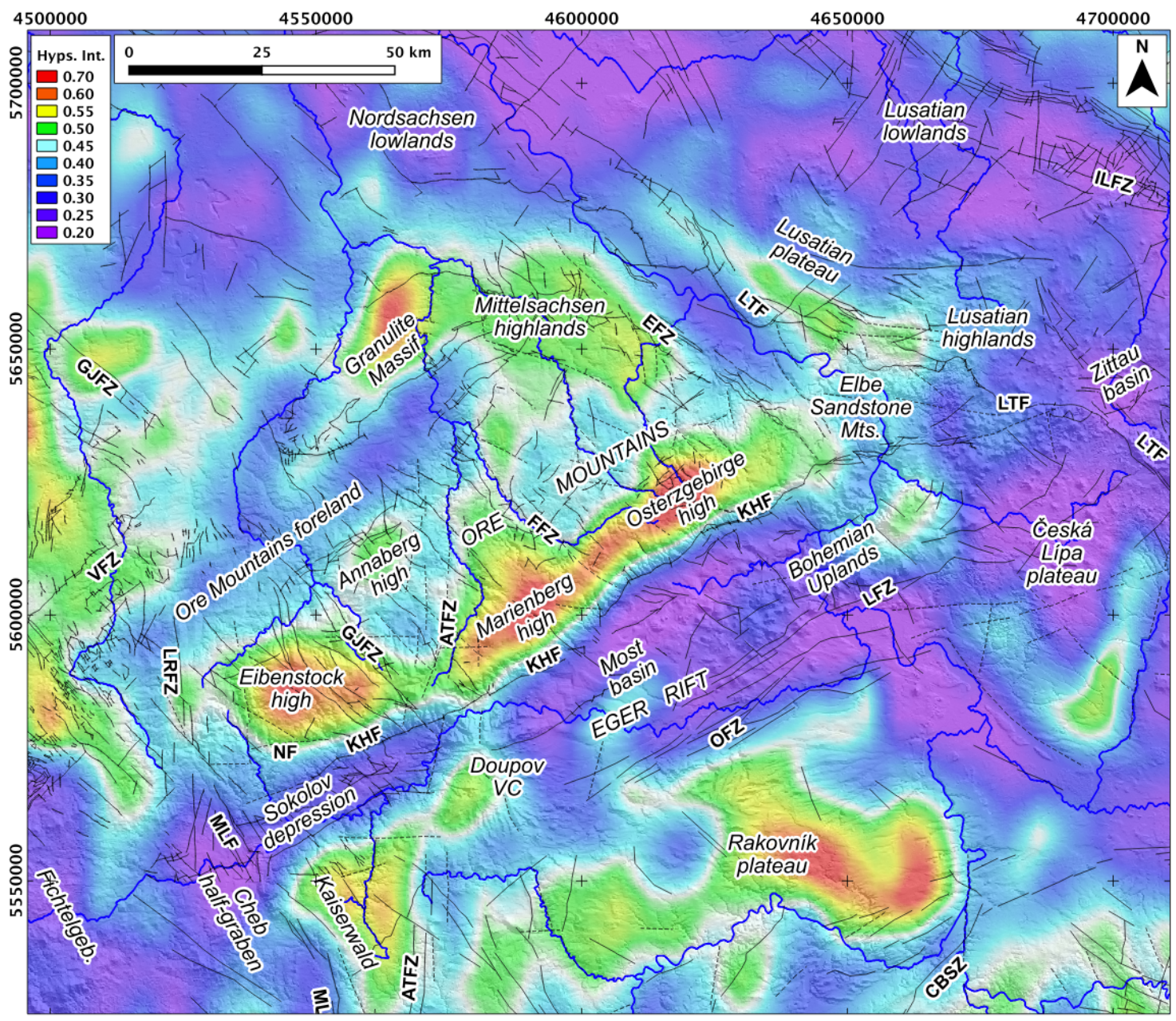

Hypsometric integral values (Figure 9 and Table 1) vary between 0.2 and 0.7 . The lowest values $(<0.3)$ correspond to flat areas with low local incisions identified in swath profiles. This is the case for the Nordsachsen and Lusatian lowlands and for areas located east of the Rakovník Plateau. NE-trending depressions related to the Eger Rift are also well outlined, as well as the Ore Mountains' foreland surface (see also Figure 7). The drainage network is well developed in the Bohemian Uplands and along the northern flank of the Ore Mountains. However, the lower hypsometric signature of these two areas is amplified by the vicinity of the topographic scarps of the Eger Rift and by the topographic contrast between the NW part of the Ore Mountains and the flatter foreland regions. The inner part of the Česká Lípa Plateau also displays low hypsometric integral values. This is related to the relatively flat topography of the 
plateau. Elevated surfaces and plateaus, which are locally incised, are associated with high hypsometric integral values $(\geq 0.5)$. The Rakovník Plateau is associated with a hypsometric high limited by the Ohře Fault Zone and the Berounka River. Peak values are found in the southern part of the plateau and reflect the entrenchment of the Berounka and Vltava rivers. The Kaiserwald hypsometric high is related both to topographic scarps (Sokolov Depression to the north and Mariánské-Lázně Fault to the west) and to the entrenchment of the Teplá River. The hypsometric signature of elevated surfaces in the Ore Mountains (Osterzgebirge, Marienberg and Eibenstock topographic highs) is amplified by the Krušné Hory Fault scarp and by the entrenchment of main rivers that border these surfaces. Some areas north of the Ore Mountains (Granulite Massif and Mittelsachsen Highlands) also display high hypsometric integral values. This is mainly due to the fact that the main rivers locally incise a relatively flat landscape. The Granulite Massif may also be highlighted, due to the fact that rivers cut through a harder rock formation. High hypsometric integral values along the Elbe River also reflect the topographic contrast between the Elbe Valley and surrounding plateau that are delimited by the Lusatian Thrust Fault and the Elbe Fault Zone.

Figure 10. Classification of landscapes (surface index, see Equation (3)) based on elevations, hypsometric integral and surface roughness. Positive values highlight elevated and preserved surfaces. Negative values reveal incised regions. See Figure 2 for abbreviations.

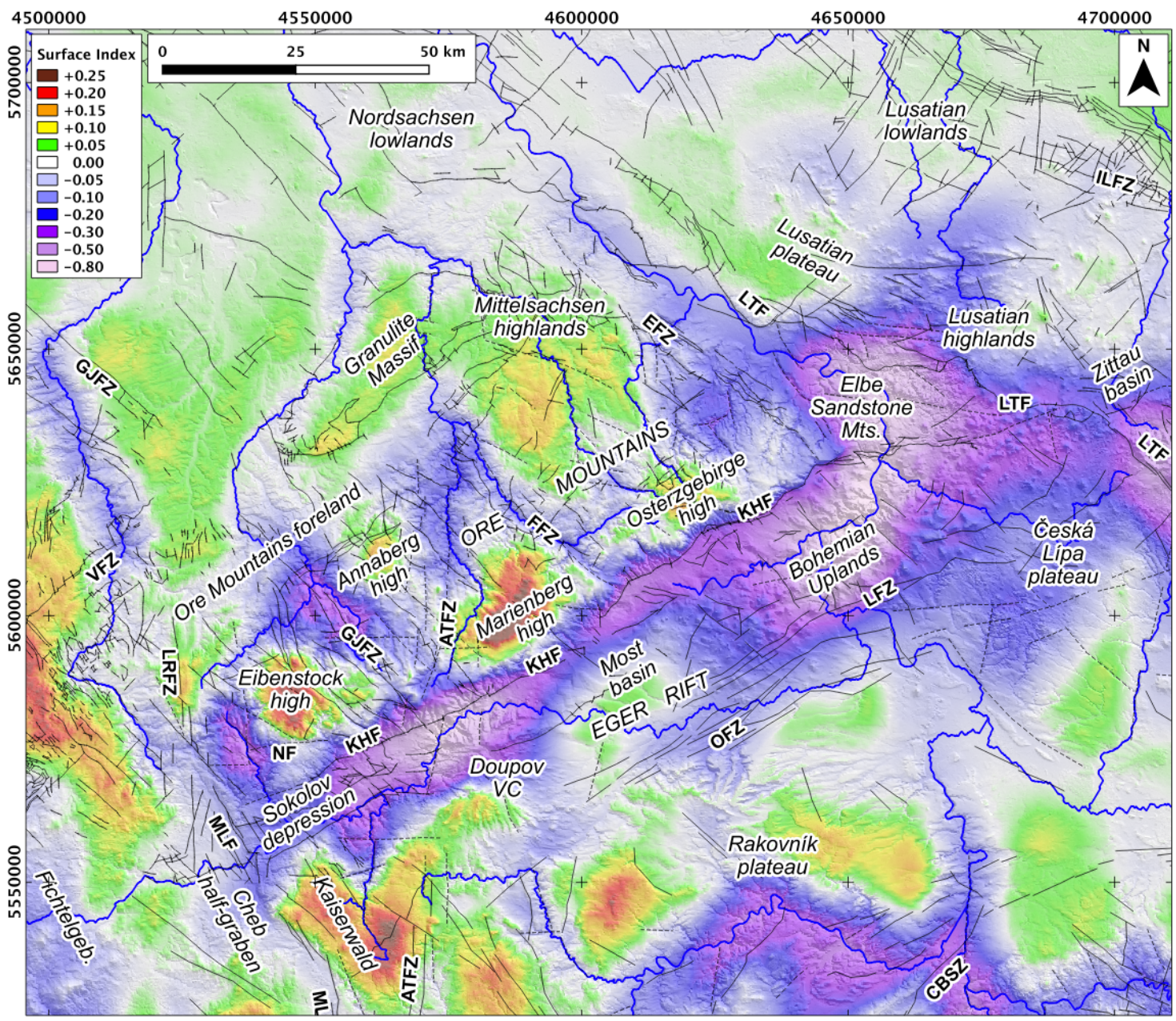


Table 1. Summary of computed geomorphic indices. We extracted pixel values and normalized steepness indices $\left(k_{s n}\right)$ for main surfaces and faulted areas discussed in the text (see the locations in Figure 2). Values were classified using quantiles (Qu.).

\begin{tabular}{|c|c|c|c|c|c|c|c|c|c|c|}
\hline \multirow[b]{2}{*}{ Area } & \multicolumn{5}{|c|}{ Hypsometric Integral } & \multicolumn{5}{|c|}{ Surface Roughness } \\
\hline & Min & 1st Qu. & Median & 3rd Qu. & Max & Min & 1st Qu. & Median & 3rd Qu. & Max \\
\hline Eibenstock High & 0.52 & 0.55 & 0.58 & 0.60 & 0.62 & 1.006 & 1.007 & 1.008 & 1.009 & 1.010 \\
\hline Marienberg High & 0.49 & 0.54 & 0.57 & 0.60 & 0.64 & 1.005 & 1.005 & 1.006 & 1.007 & 1.008 \\
\hline Osterzgebirge High & 0.45 & 0.49 & 0.55 & 0.59 & 0.65 & 1.005 & 1.006 & 1.007 & 1.008 & 1.009 \\
\hline Ore Mountains foreland & 0.33 & 0.37 & 0.39 & 0.41 & 0.45 & 1.002 & 1.002 & 1.003 & 1.003 & 1.004 \\
\hline Granulite Massif & 0.39 & 0.45 & 0.49 & 0.53 & 0.60 & 1.001 & 1.001 & 1.002 & 1.002 & 1.002 \\
\hline Mittelsachsen Highlands & 0.42 & 0.45 & 0.48 & 0.51 & 0.53 & 1.001 & 1.002 & 1.002 & 1.003 & 1.004 \\
\hline Nordsachsen Lowlands & 0.18 & 0.26 & 0.33 & 0.39 & 0.47 & 1.000 & 1.000 & 1.000 & 1.001 & 1.002 \\
\hline Elbe Sandstone Mountains & 0.32 & 0.38 & 0.41 & 0.44 & 0.47 & 1.004 & 1.007 & 1.009 & 1.012 & 1.013 \\
\hline Lusatian highlands & 0.23 & 0.31 & 0.36 & 0.40 & 0.47 & 1.000 & 1.001 & 1.001 & 1.001 & 1.002 \\
\hline Bohemian upland volcanics & 0.22 & 0.27 & 0.32 & 0.40 & 0.47 & 1.004 & 1.005 & 1.007 & 1.010 & 1.014 \\
\hline Česká Lípa Plateau & 0.16 & 0.23 & 0.32 & 0.39 & 0.48 & 1.001 & 1.002 & 1.003 & 1.004 & 1.005 \\
\hline Most Basin & 0.27 & 0.31 & 0.36 & 0.41 & 0.45 & 1.001 & 1.001 & 1.001 & 1.001 & 1.002 \\
\hline Rakovník Plateau & 0.37 & 0.44 & 0.50 & 0.54 & 0.61 & 1.001 & 1.002 & 1.003 & 1.004 & 1.005 \\
\hline Kaiserwald Massif & 0.43 & 0.47 & 0.51 & 0.54 & 0.57 & 1.003 & 1.004 & 1.004 & 1.005 & 1.007 \\
\hline Elbe Fault Zone & 0.35 & 0.43 & 0.46 & 0.49 & 0.53 & 1.002 & 1.003 & 1.004 & 1.006 & 1.007 \\
\hline Flöha Fault Zone & 0.44 & 0.45 & 0.48 & 0.52 & 0.60 & 1.004 & 1.005 & 1.005 & 1.007 & 1.009 \\
\hline Annaberg Fault Zone & 0.41 & 0.43 & 0.45 & 0.46 & 0.49 & 1.005 & 1.005 & 1.006 & 1.006 & 1.006 \\
\hline Gera-Jáchymov Fault Zone & 0.41 & 0.43 & 0.46 & 0.49 & 0.53 & 1.006 & 1.007 & 1.008 & 1.009 & 1.011 \\
\hline Northern flank of Eger Rift & 0.30 & 0.36 & 0.42 & 0.47 & 0.51 & 1.005 & 1.006 & 1.007 & 1.009 & 1.013 \\
\hline Southern flank of Eger Rift & 0.20 & 0.30 & 0.35 & 0.40 & 0.48 & 1.001 & 1.002 & 1.003 & 1.006 & 1.008 \\
\hline
\end{tabular}

\begin{tabular}{lcccccccccc}
\hline & \multicolumn{4}{c}{ Surface Index } & \multicolumn{4}{c}{ Normalized Steepness Index } \\
\hline \multicolumn{1}{c}{ Area } & Min & 1st Qu. & Median & 3rd Qu. & Max & Min & 1st Qu. & Median & 3rd Qu. & Max \\
\hline Eibenstock High & -0.09 & -0.02 & 0.04 & 0.13 & 0.22 & 5 & 19 & 36 & 51 & 85 \\
Marienberg High & -0.05 & 0.02 & 0.08 & 0.17 & 0.25 & 4 & 16 & 27 & 46 & 66 \\
Osterzgebirge High & -0.09 & -0.04 & -0.01 & 0.04 & 0.11 & 6 & 19 & 27 & 36 & 52 \\
Ore Mountains foreland & -0.11 & -0.05 & -0.01 & 0.01 & 0.04 & 5 & 13 & 18 & 26 & 40 \\
Granulite Massif & -0.02 & 0.01 & 0,04 & 0.07 & 0.10 & 5 & 9 & 14 & 20 & 39 \\
Mittelsachsen Highlands & -0.01 & 0.01 & 0.05 & 0.08 & 0.12 & 5 & 11 & 16 & 23 & 36 \\
Nordsachsen Lowlands & -0.02 & 0.00 & 0.01 & 0.02 & 0.05 & 2 & 4 & 7 & 11 & 21 \\
Elbe Sandstone Mountains & -0.73 & -0.62 & -0.47 & -0.33 & -0.19 & 2 & 13 & 25 & 40 & 80 \\
Lusatian Highlands & -0.05 & -0.01 & 0.00 & 0.02 & 0.04 & 2 & 4 & 8 & 11 & 20 \\
Bohemian upland volcanics & -0.80 & -0.51 & -0.32 & -0.24 & -0.18 & 7 & 19 & 31 & 50 & 83 \\
Česká Lípa Plateau & -0.27 & -0.17 & -0.13 & -0.02 & 0.05 & 3 & 8 & 12 & 17 & 27 \\
Most Basin & -0.06 & -0.02 & 0.00 & 0.03 & 0.05 & 2 & 6 & 15 & 19 & 40 \\
Rakovník Plateau & -0.12 & -0.03 & 0.01 & 0.05 & 0.13 & 3 & 8 & 14 & 21 & 37 \\
Kaiserwald Massif & -0.10 & 0.03 & 0.11 & 0.16 & 0.22 & 4 & 10 & 21 & 36 & 62 \\
Elbe Fault Zone & -0.22 & -0.16 & -0.11 & -0.06 & -0.02 & 5 & 17 & 26 & 41 & 57 \\
Flöha Fault Zone & -0.15 & -0.11 & -0.08 & -0.04 & 0,01 & 10 & 23 & 28 & 35 & 63 \\
Annaberg Fault Zone & -0.19 & -0.15 & -0.11 & -0.06 & 0.00 & 11 & 25 & 31 & 38 & 60 \\
Gera-Jáchymov Fault Zone & -0.33 & -0.25 & -0.17 & -0.11 & -0.05 & 10 & 27 & 39 & 47 & 64 \\
Northern flank of Eger Rift & -0.58 & -0.34 & -0.24 & -0.15 & -0.06 & 7 & 23 & 51 & 77 & 374 \\
Southern flank of Eger Rift & -0.35 & -0.17 & -0.09 & -0.05 & 0.01 & 3 & 11 & 22 & 42 & 65 \\
\hline & & & & & & & & & \\
\hline
\end{tabular}


The classification based on computed surface roughness and the hypsometric integral is displayed in Figure 10. Surface index values vary between -0.8 and 0.25 . Most of the surfaces identified in swath topographic profiles are associated with positive surface index values. However, our index does not highlight some flat areas when they are associated with extremely low hypsometric integral values (e.g., Česká Lípa Plateau). Negative surface index values are mainly located along the major rivers. Lowest values $(<-0.3)$ are found along deeply entrenched portions of rivers, such as the Elbe River in the Bohemian Uplands and the Elbe Sandstone Mountains, the Berounka river south of the Rakovník Plateau, the Schwarzwasser in the western part of the Ore Mountains and tributaries of the Eger (e.g., Teplá and Svatava rivers) draining in the Sokolov Depression. Others major rivers (e.g., Weiße Elster, Mulde, Zschopau, Flöha) are highlighted by less negative ( -0.3 to 0 ) surface index values.

\subsection{Drainage Network}

We analyzed and extracted $k_{s n}$ values from $\sim 3000$ streams and rivers (Figure 11 and Table 1). We divided $k_{s n}$ values in 10 classes (denoted Q1 to Q10 in Figure 11) using quantiles. Lower $k_{s n}$ values $(<20)$ are mainly found in Miocene deposits, in sedimentary depressions of the Eger Rift and within the Bohemian Cretaceous Basin (Figure 2). The Variscan Metamorphic Complex of the Ore Mountains (Figure 2) displays higher $k_{s n}$ values (>20). However, variations in $k_{s n}$ values cannot be only explained by lithological changes. In many instances areas with the same lithology may experience significant variations in $k_{s n}$ values.

The highest $k_{s n}$ values (class Q10 in Figure 11) are mainly distributed along the northern rim of the Eger Rift. Segments of river profiles located south of the main drainage divide of the Ore Mountains are steep, while segments located within the Eger Rift depression display more gentle gradients. As a result, the scarps related to the NE-trending Krušné Hory and E-trending Nejdek faults are particularly well highlighted by $k_{s n}$ values up to 374 (Figure 11). The southern border of the Sokolov Depression is also associated with high $k_{s n}$ values, while river profiles located along the Ohře (Eger) Fault Zone display less intense gradients. We also observe high $k_{s n}$ values along the NE-trending Bohemian Uplands' volcanic field. Segments with high $k_{s n}$ values $(\geq 50)$ are also found within the central and western portions of the Ore Mountains (Figure 11). These values seem to be associated with major lineaments, such as the Annaberg-Teplá, Flöha and Gera-Jáchymov fault zones. By contrast, most of the areas located in the eastern part of the Ore Mountains (between the Flöha and Elbe fault zones and referred to as the Mittelsachsen Highlands in Figure 2) show lower $k_{s n}$ values.

The distribution of $k_{s n}$ values in the tilted Ore Mountains reflects the complexity of river profiles. Longitudinal profiles along the Ore Mountains (Figure 12) display several knickpoints, which represent the limit between three well-defined segments. There is no correspondence between knickpoints and changes in rock-type. The uppermost segments are associated with the Eibenstock, Marienberg and Osterzgebirge topographic highs (Profiles 1 to 4 in Figure 12). They are slightly concave in Profiles 1 to 3 and convex in Profile 4. Reconstructed base-levels using these segments are steeper in the eastern and central parts of the Ore Mountains (Profiles 1 and 2 in Figure 12) than in the west (Profiles 3 in Figure 12). These upper segments are separated from central segments by prominent knickpoints. Central segments are well defined, and their concavity increases westward. They are separated from the present-day base-level by a 
minor knickpoint mostly located within the Granulite Massif. The comparison between reconstructed profiles and the present-day river profiles show that these knickpoints are associated with a 50- to 100-m base-level change.

East of the Ore Mountains, anomalies in river profiles highlighted by high $k_{s n}$ values are mainly found along tributaries of the Elbe River located between the Elbe Fault Zone and the Lusatian thrust (Figure 11). Figure 13 displays characteristic longitudinal profiles for tributaries of the Elbe river. The upper segments of eastern tributaries (Profiles 1 to 4 in Figure 13) correspond to the almost flat topography of the Lusatian Plateau, which is limited to the east by the Lusatian Thrust. These upper segments are limited by prominent knickpoints and are separated from the Elbe River by convex segments, which coincide with the Lusatian Thrust. Reconstruction of the upper segments shows that these knickpoints are associated with an 80- to 140-m base-level change. The longitudinal profiles of western tributaries (Profiles 5 to 8 in Figure 13) display one or two knickpoints. Reconstruction of different segments indicates that the uppermost segments are associated with a 160- to 250-m base-level change, while lower segments are associated with a 70 - to 110-m base-level change.

Figure 11. Normalized steepness indices $\left(k_{s n}\right)$ extracted from stream longitudinal profiles. Values are classified using 10 quantiles (denoted Q1 to Q10). Bold lines represent the simplified trace of major lineaments (see Figure 2 for abbreviations).

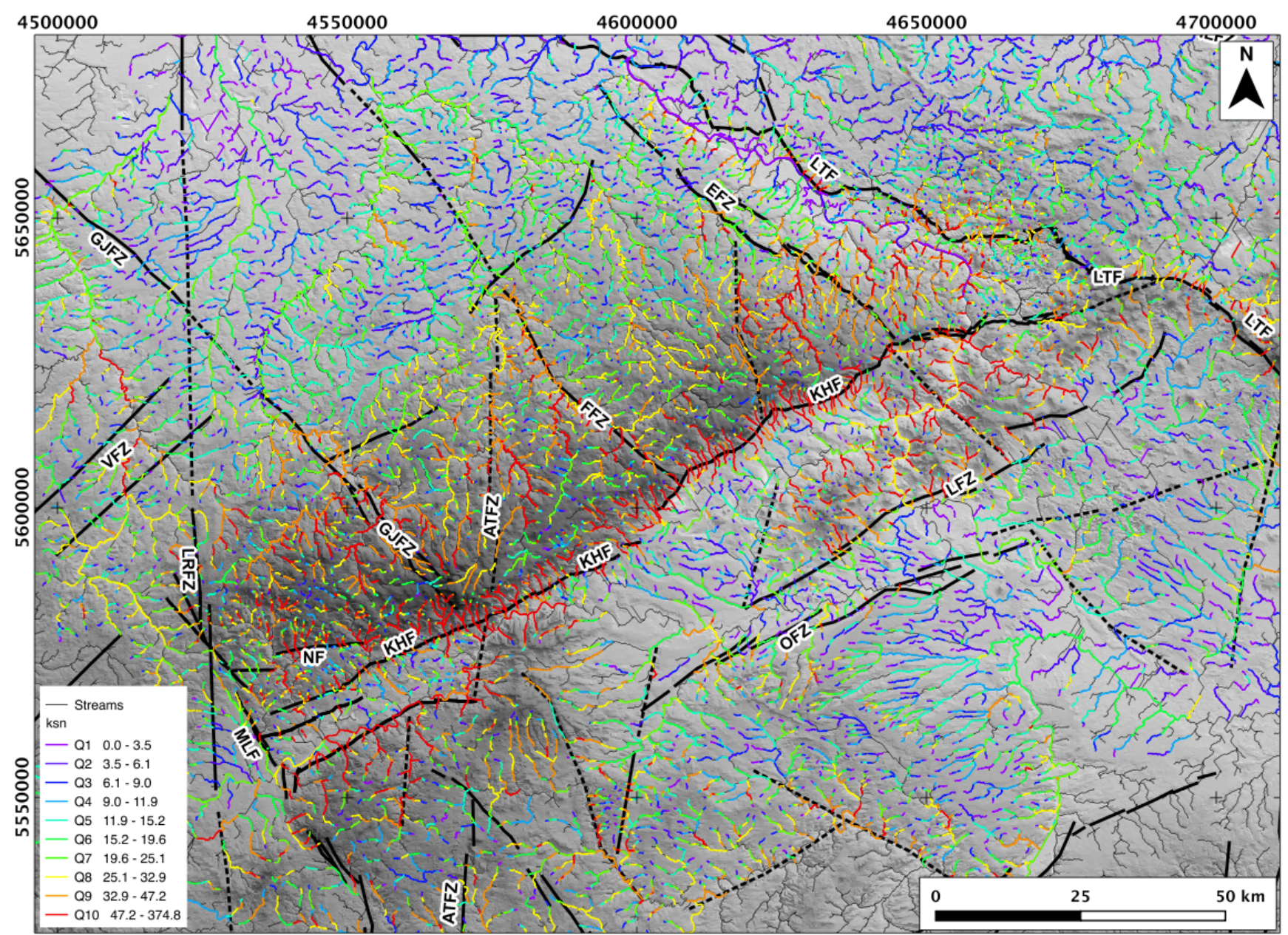


Figure 12. Examples of longitudinal river profiles from the Ore Mountains (extracted from 20-m resolution DEM). Red points indicate the main knickpoints. Red lines and grey shades show reconstructed profiles using segments located above knickpoints (the method is explained in Figure 6C). Distances are in kilometers, and elevations are in meters.

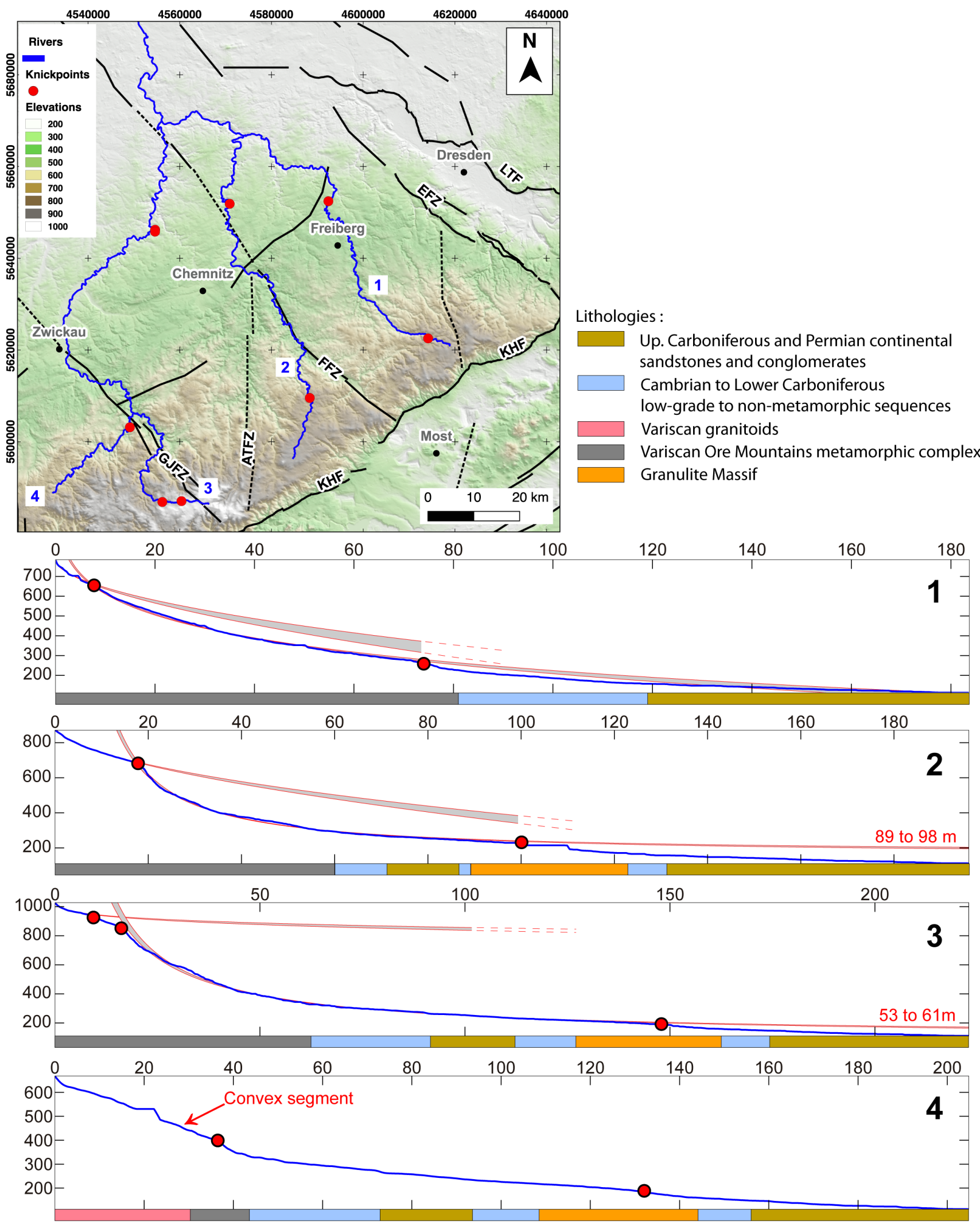


Figure 13. Examples of longitudinal river profiles from the tributaries of the Elbe River. Red points indicate the main knickpoints. Red lines and grey shades show reconstructed profiles using segments located above knickpoints (the method is explained in Figure 6C). Distances are in kilometers, and elevations are in meters.

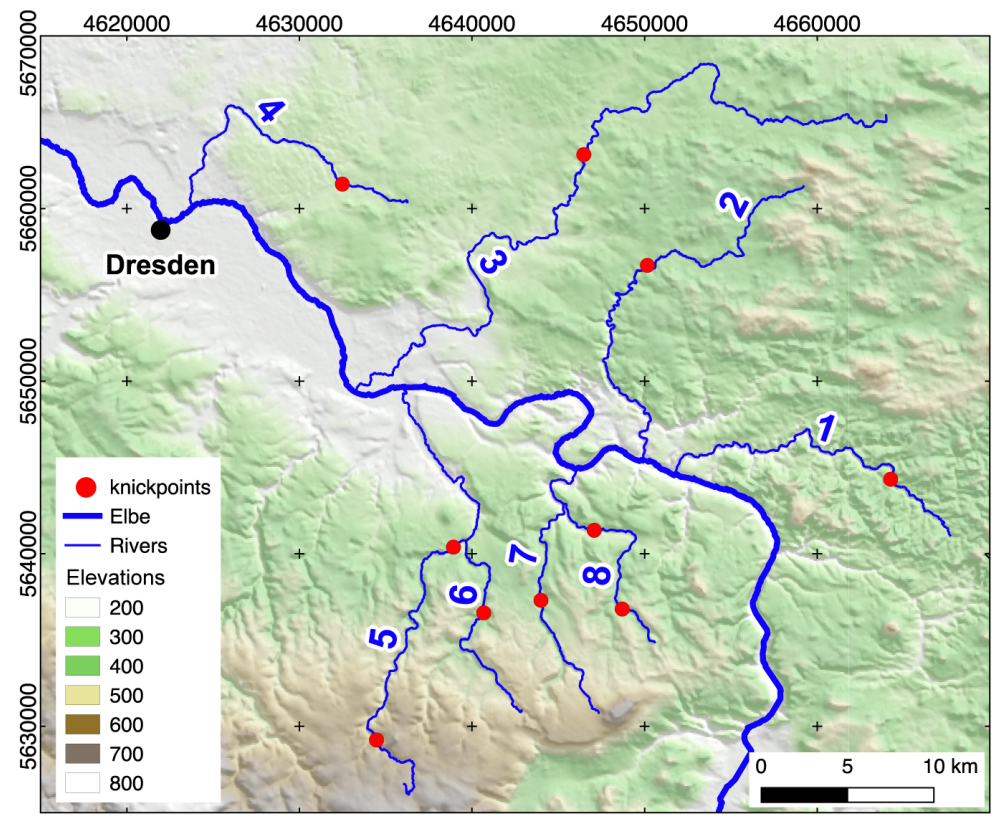

Lithologies:

$\square$ Late Cretaceous sandstones and claystones Up. Carboniferous and Permian continental sandstones and conglomerates Variscan granitoids

$\square$ Variscan Ore Mountains metamorphic complex Cadomian Lusatian granodiorite complex
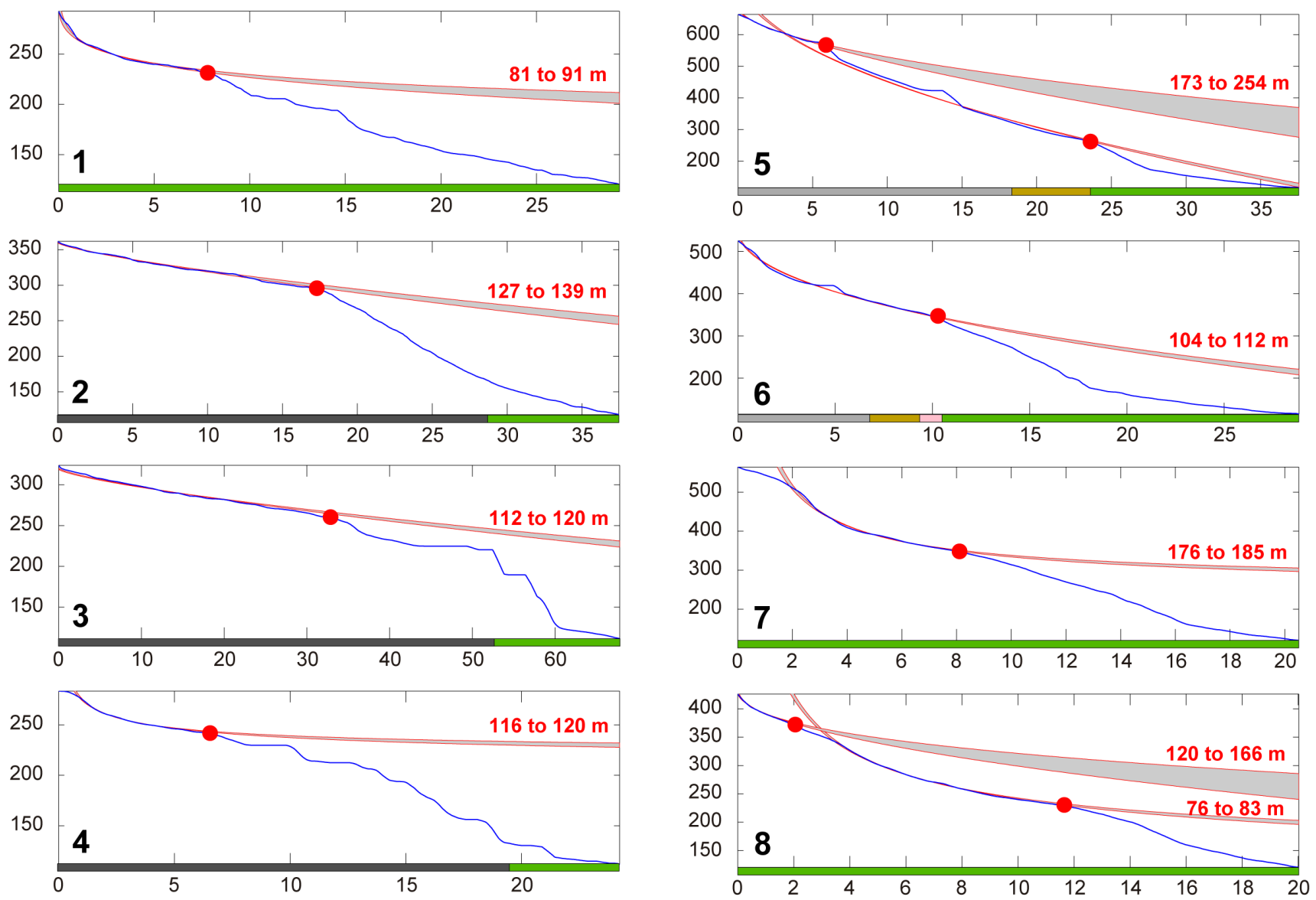


\subsection{Uncertainties Related to DEMs and Methods}

Extracted geomorphic indices are inevitably affected with uncertainties and errors related to the quality and sampling of the DEM. Free and commonly used data include the one arc-second ( $\mathrm{ca} .30 \mathrm{~m}$ )-resolution ASTER GDEM and the three arc-second ( $c$ a. $90 \mathrm{~m}$ )-resolution SRTM. For both datasets, the absolute vertical error is reported to be less than $20 \mathrm{~m}$. We tested the sensitivity of calculated hypsometric integral (HI) and surface roughness (SR) values to changes in spatial resolutions (Figure 14A,B). For both ASTER and SRTM datasets, we calculated HI and SR using a fixed 9-km window centered on the same geographic coordinates. We also used resampled datasets with resolution ranging between 60 and $300 \mathrm{~m}$. ASTER and SRTM data provide similar HI values (Figure 14A). HI values are slightly affected by the resolution of the DEM. For each analyzed area, the difference between maximum and minimum HI values does not exceed 0.08. SR is more dependent on the quality of the original dataset, as well as on the resolution of the DEM. SR values derived from ASTER are 10\% to 50\% higher than those derived from SRTM data (Figure 14B). SR values also decrease significantly for lower resolutions. This is mainly related to the fact that lower resolutions reduce the imprint of the drainage network and "smooth" the initial topography. It becomes thus more problematic to differentiate between different areas at lower resolutions. The SRTM appears thus to be adapted to our surface analyses. ASTER data would provide a greater precision for SR analyses, but would also require more computational time. Coarse resolution should be avoided.

Figure 14. (A,B) Hypsometric integral and surface roughness calculated for different DEM resolutions; (C,D) hypsometric integral and surface roughness calculated using different windows (in pixels).

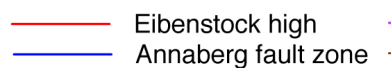

Annaberg fault zone
Elbe Sandstone Mts Mittelsachsen highlands Nordsachsen lowlands
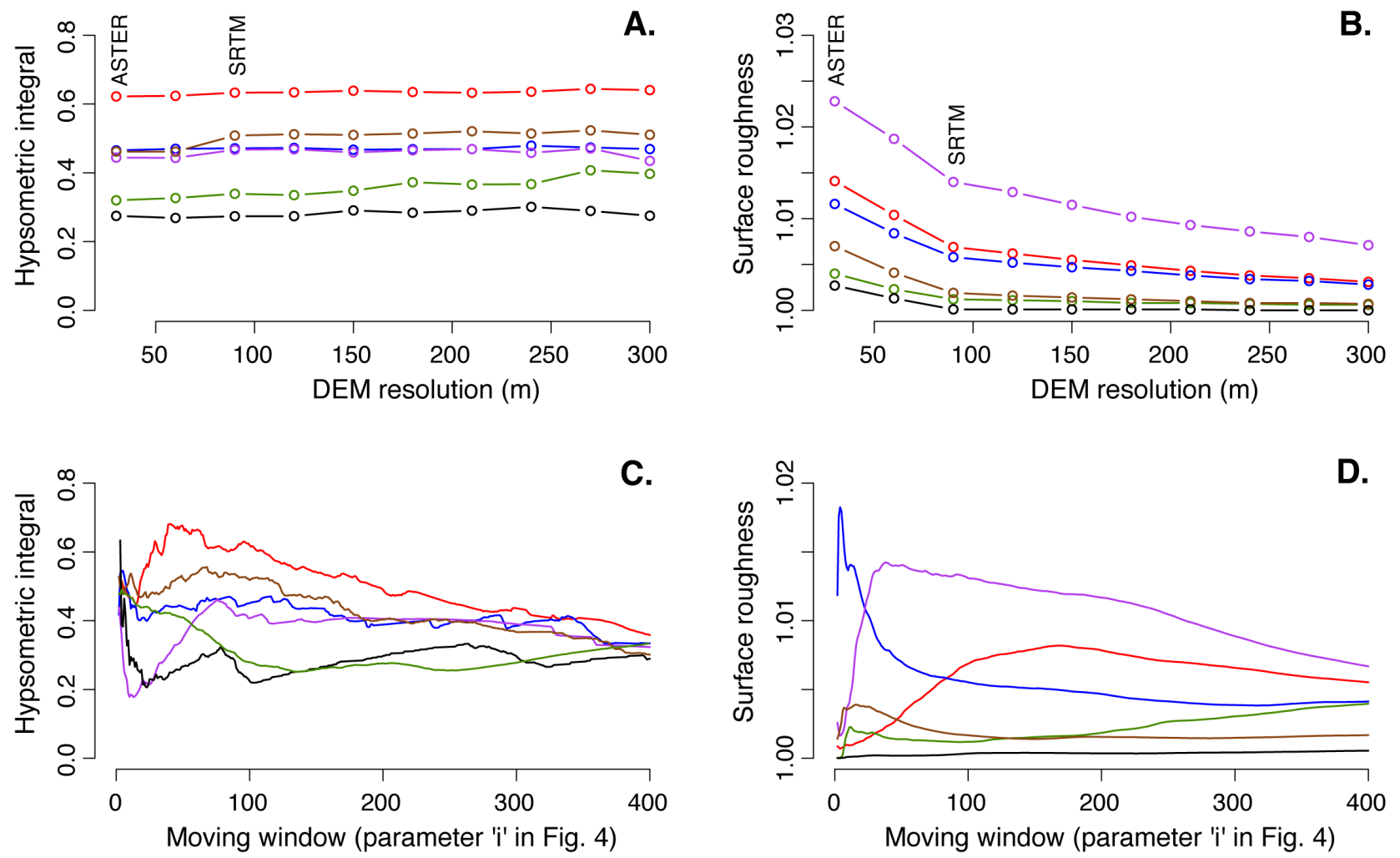
The size of the moving window is the most sensitive parameter in surface analyses. A meaningful moving window should be large enough to encompass a large portion on the analyzed landscape; otherwise, it will reflect local-scale variations in topography. It should, for instance, contain several valleys or ridges. In addition, tectonic features may produce very large depressions or topographic highs, which significantly affect indices for neighboring areas. These effects must be taken into account when interpreting results from a larger moving window. The moving window size also affects computational time. We calculated HI and SR using SRTM data and different window sizes (up to 400 pixels) centered on the same geographic coordinates (Figure 14C,D). Below 50 pixels, most of the calculated HI and SR values increases or drop quickly as the size of the moving window increases. This suggests a strong effect from local topography. Most of calculated indices display a more stable pattern (i.e., smooth changes) between 100 and 250 pixels. This indicate that the topography is correctly averaged. However, HI values are very sensitive to the size of the moving window, especially in flat areas (Most Basin and lowlands). In most of the areas, HI and SR values converge towards a similar value ( 0.35 for $\mathrm{HI}$ and 1.005 for SR) as the size of the moving window increases. Our surface analyses are based on a 100-pixel moving window. This size is adapted for this study, as it avoids local topographic effects and requires a reasonable computational time.

Extracted drainage network and contributing areas are also affected by the quality and sampling of the DEM. Additional known biases are related to methodological aspects. In our study area, commonly encountered problems concern nested depressions, which are related either to DEM imperfections (mainly found along entrenched rivers) or to opencast mines. These pits need to be filled to create flow directions. The original topography is also affected by human artifacts, such as dammed rivers, which replace valleys with flat areas. Artificial flats related to DEM filling or dammed rivers introduce errors in extracted river paths. In spite of being commonly used, the D8 algorithm used as the flow-routing method has received much criticism. This algorithm introduces bias in flow path orientation as it decomposes flow directions into units of $45^{\circ}$ [76]. It also tends to produce parallel flow lines in flat areas. The integer format of many DEMs also locally produces multiple flats with zero slope, which cannot be handled in a log-log plot of slope and area (e.g., [22]). This issue is commonly solved by smoothing extracted river profiles. However, this also induces bias in extracted indices, especially for segments located close to major knickpoints. In this study, we smoothed extracted river profiles using a 400-m moving window.

\section{Discussion}

The Ore Mountains and Eger Rift are well known from a geologic and structural point of view. However, little is known about the tectonic features responsible for the present-day topography, especially in the Ore Mountains, where most of the outcrops are Paleozoic or Mesozoic. If we except river terraces and a few outcrops located along the Krušné Hory Fault [34,49], no recent stratigraphic markers can be used to constrain the age or motion of major faults and lineaments in the Ore Mountains. In this context, a DEM-based analysis of landscapes represents a powerful tool for evaluating the influence of recent tectonics. 


\subsection{Morpho-Tectonic Interpretation of the Ore Mountains}

Landscapes evolve as a consequence of interactions between competing processes driven by climate and tectonics (e.g., [87-89], and the references therein). Elevated landscapes may persist though time in a dynamic equilibrium, with topography largely controlled by the variable erodibility of rock units ([87,89,90], and the references therein). Landscapes affected by recent tectonic or climatically-induced base-level drop are characterized by a propagating front of river incision, representing the boundary between an upper-relict landscape and a lower-actively adjusting zone (e.g., [2-5,85]). Swath topographic profiles in Figure 7 show that the highest portions of the Ore Mountains consist of elevated surfaces. In the analyzed river longitudinal profiles, we observe an upper reach that is associated with these elevated surfaces. These surfaces likely correspond to the relicts of an old landscape developed in base-level conditions different from the present ones. River profiles also display a central segment that is more concave and could record an uplift input. Central segments are separated from the lowermost reaches by minor knickpoints, which may indicate a new change in base-level conditions, induced by tectonics or climate.

DEM-based surface indices successfully highlight the uplifted relicts of the old landscape and the response of the rivers to this uplift. Uplifted surfaces observed in swath profiles mainly coincide with the high hypsometric integral values ( $>0.5$ in Figure 9$)$. Areas that are preferentially incised by the drainage network are mainly associated with peak values in surface roughness (Figure 8). The surface index presents a real interest here. The combination of both hypsometric integral and surface roughness within a unique index allows displaying on the same map the preserved surfaces with positive values and preferentially incised areas with negative values (Figure 10). This helps to locate both relicts of old landscapes and transient topography.

Discontinuities observed in the surface index map (Figure 10) suggest that the distribution of both topographic surfaces and the main incisions by the drainage network is tightly controlled by tectonics. As fractured rocks are easily eroded and incised by rivers, major lineaments are outlined by an increase in topography roughness. Negative surface index values are mainly located along N- and NW-trending lineaments, which are, from west to east, the Mariánské-Lázně, Gera-Jáchymov, Annaberg-Teplá, Flöha and Elbe fault zones. These lineaments delimitate three elevated surfaces (referred to as the Eibenstock, Marienberg and Osterzgebirge topographic highs) and a set of lower surfaces (e.g., Annaberg High and Mittelsachsen Highlands). The Ore Mountains would be thus divided into several compartments, rather than a single and homogeneous tilted block (Figure 15). The erosion of these compartments is mainly produced along their boundaries, while their inner parts are still largely preserved. The compartmented structure of the Ore Mountains could be related to the present-day state of stress in Central Europe. Seismological data from the western tip of the Ore Mountains and Vogtland show that earthquake swarms are mainly triggered along NNW-trending left-lateral and NW-trending right-lateral faults (e.g., [38,43]). The stress field inverted from the focal mechanisms indicates a NW compression and an NE extension, which is consistent with that of Western Europe (e.g., [38,39,43,65], and the references therein). Our interpretation is that $\mathrm{N}$ - and NW-trending lineaments mainly act as strike-slip faults with a minor normal component that accommodates the NW shortening and NE extension. The uppermost topographic surfaces 
could be related to uplifted compartments, while intermediate surfaces, such as the Annaberg High, could be associated with downthrown compartments.

Figure 15. Interpretation of the recent morpho-tectonic framework based on the main discontinuities from geomorphic indices. Faults abbreviations: ATFZ, Annaberg-Teplá Fault Zone; EFZ, Elbe Fault Zone; FFZ, Flöha Fault Zone; GJFZ, Gera-Jáchymov Fault Zone; KHF, Krušné hory Fault; LFZ, Litoměřice Fault Zone; LTF, Lusatian Thrust Fault; MLF, Mariánské-Lázně Fault; OFZ, Ohře Fault Zone.
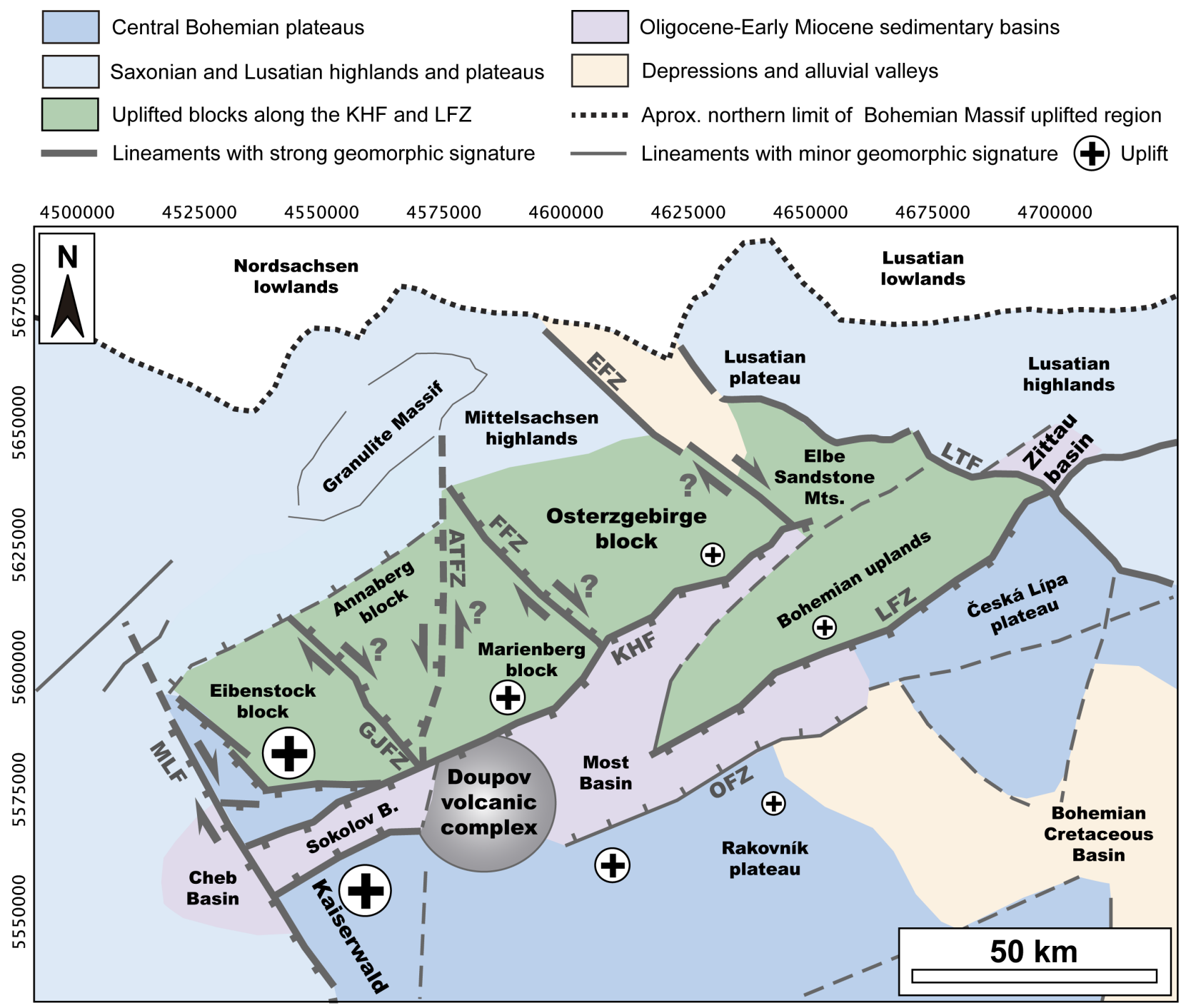

Topographic analyses also suggest a westward increase in the amount of uplift. The elevation of uppermost surfaces increases along-strike from $\sim 800 \mathrm{~m}$ to $\sim 1000 \mathrm{~m}$. Swath profiles, as well as geomorphic maps indicate a substantial increase of erosional processes in the western part of the Ore Mountains. The Schwarzwasser and Svatava drainage networks (western Ore Mountains, see the location in Figure 5) are highlighted by high surface roughness and negative surface index values, while the Freiberg Mulde (eastern Ore Mountains, see the location in Figure 5) display lower surface roughness and mostly positive surface index values. We also observe a westward increase in the overall concavity of intermediate segments in river profiles (Figure 12), as well as an increase in $k_{s n}$ values (Figure 11). 
As the lithology of the Ore Mountains is rather homogeneous, observed variations in $k_{s n}$ values could show a direct proportionality with uplift rates (e.g., [22,79]). The convex shape of the Zwickauer Mulde upper reach could also indicate that in the westernmost part of the Ore Mountains, rivers cannot counterbalance the uplift.

\subsection{Asymmetry of the Eger Rift}

Our swath topographic profiles (Figure 7) illustrate the asymmetry between both shoulders of the Eger Rift. The Ore Mountains represent the footwall flexural uplift of the Krušné Hory Fault. As a result, the well-expressed Krušné Hory Fault scarp is identified by sharp discontinuities in our morphometric maps (Figures 8-10). By contrast, the Rakovník Plateau, located south of the Ohře Fault Zone, remains at low and almost constant elevations. The Ohře Fault Zone forms a minor topographic scarp and is mainly defined in our hypsometric integral map (Figure 9). It remains poorly defined in surface roughness and surface index maps (Figures 8 and 10).

The asymmetry between both shoulders of the Eger Rift is also illustrated by anomalies in the drainage network. Anomalies in river longitudinal profiles are concentrated along the Krušné Hory Fault (Figure 11). High $k_{s n}$ values are likely to reflect present-day bedrock incision along the Krušné Hory Fault scarp. According to Walther et al. [34], the main uplift of the Ore Mountains could not be older than the Pliocene. Incision by the rivers could be thus related to the recent modification of the local base level in response to the topographic uplift of the Ore Mountains.

As for the Ore Mountains, our topographic analyses also suggest a westward increase in the amount of uplift along the southern shoulder of the Eger Rift. Swath profiles (Figure 7) show that topographic surfaces become more tilted toward the west. Local relief in swath profiles, as well as geomorphic maps suggest more incision in the western part of the Eger Rift. Anomalies in river longitudinal profiles (Figure 11) are mainly observed south of the Sokolov Depression. The western tip of the Eger Rift, as well as the Mariánské-Lázně Fault show evidence of active tectonics (e.g., [37,44,47]). These anomalies could be triggered by recent base-level changes related to the uplift of the Kaiserwald Massif. The drainage network located along the Ohře fault scarp displays lower $k_{s n}$ values. This suggests very limited changes with respect to the Eger River base-level along the Ohře Fault Zone.

\subsection{Entrenched Drainage Network}

Previous works pointed out the entrenchment of the drainage network, especially at the eastern tip of the Ore Mountains (tributaries of the Elbe River) and in the region east of Prague (Berounka and Vltava rivers) $[48,49,91]$. Our DEM-based analysis of surfaces and the drainage network allows us to precisely map the effect of this entrenchment. High $k_{s n}$ values (Figure 11), which are likely to reflect present-day bedrock incision, are mainly found north of the Litoměřice Fault Zone and between the Elbe Fault Zone and the Lusatian Thrust.

The analysis of longitudinal profiles for tributaries of the Elbe River suggests an 80- to 140-m base-level fall (Figure 13). Our analysis based on river profiles is consistent with the position of the highest Plio-Quaternary terraces in the Elbe valley, which are located at $\sim 100 \mathrm{~m}$ above the present-day base-level of the Elbe River [92]. The entrenchment of the Elbe River and the resulting modification of 
the local base level could be in fact related to a local topographic uplift of the Bohemian Uplands along the NE-trending Litoměřice Fault Zone and the Lusatian and Česká Lipa plateaus along the Lusatian thrust (Figure 15). Recent motion along the Lusatian Thrust is attested to by the uplift of a sandstone sequence along a NW trending post-Miocene fault in the area south of Zittau [93].

\section{Conclusions}

We tested the sensitivity of DEM-based geomorphic analyses in the slowly deformed regions surrounding the Eger Rift in Central Europe. Our approach relies on the analysis of swath topographic profiles, the extracted drainage network and topographic surfaces. These methods are complementary, and their combined use thus allows a better evaluation of the influence of recent tectonics on landscapes. Swath topographic profiles allow us to identify several flat topographic surfaces with elevations up to $1000 \mathrm{~m}$ and to quantify the incision of these surfaces by the drainage network ( $c a .100$ to $200 \mathrm{~m}$ ). Surface roughness (SR) can be used as a proxy to assess the spatial distribution of incisions by the drainage network. Areas with entrenched rivers are associated with surface roughness values between 1.005 and 1.015. Surface roughness also allows one to detect flat topographic surfaces located below $c a .400 \mathrm{~m}$ $(\mathrm{SR}<1.02)$. The hypsometric integral $(\mathrm{HI})$ provides a better proxy for elevated surfaces $(\mathrm{HI}>0.5)$, as well as for tectonic depressions $(\mathrm{HI}<0.3)$. We propose to combine surface roughness and the hypsometric integral. The new index (referred to as "surface index") provides a qualitative way to display flat (positive values) and eroded (negative values) areas on the same map and, thus, facilitate the interpretation of landscapes. The analysis of river longitudinal profiles proves to be useful in detecting major incisions by the drainage network. Our results show that anomalously steep segments in river profiles (evidenced by $k_{s n}$ values between 50 and 374) are mainly found in areas with entrenched rivers and along tectonic lineaments. However, using this method to produce a detailed regional-scale map requires the extraction and analysis of a great number of streams ( 3000 in this study).

The interpretation of discontinuities associated with the mapped geomorphic indices allowed us to unravel the structural control on the landscapes. The NE-trending Eger Rift and its shoulders can be clearly identified in our geomorphic maps. Areas located south of the Eger Rift (Kaiserwald Massif and Rakovník Plateau) form an almost continuous structural panel. Within this domain, indices are consistent with an uplift of the Kaiserwald Massif, possibly related to NNW-trending structures, such as the Mariánské-Lázně Fault System. The Ore Mountains form the northern shoulder of the Eger Rift and are mainly tilted along the Krušné Hory Fault. Discontinuities in mapped geomorphic indices suggest that the Ore Mountains are divided into several compartments, rather than a single and homogeneous tilted block. The compartments are delimited by N- and NW-trending lineaments (from west to east, the Mariánské-Lázně, Gera-Jáchymov, Annaberg-Teplá, Flöha and Elbe fault zones). Geomorphic indices suggest that topographic uplift increases significantly westward along both the Ore Mountains and the southern flank of the Eger Rift. Finally, the analysis of river profiles suggests that the entrenchment of the drainage network at the eastern tip of the Ore Mountains is related to topographic uplift along the NE-trending Litoměřice Fault Zone and the NW-trending Lusatian Thrust. 


\section{Acknowledgments}

This research was part of the "Junge (känozoische) tektonische Entwicklung in Kristallingebieten in Sachsen" project. Financial support was provided by the Sächsisches Landesamt für Umwelt, Landwirtschaft und Geologie. The authors acknowledge the four anonymous reviewers. Their comments and suggestions greatly improved the quality of this paper. The authors used Quantum GIS (licensed under the GNU General Public License and available at http://www.qgis.org/).

\section{Author Contributions}

All authors contributed with ideas and discussions. Louis Andreani, Richard Gloaguen and Leomaris Domínguez-González carried out the geomorphic analyses. Louis Andreani, Klaus P. Stanek, Richard Gloaguen and Ottomar Krentz interpreted the results. Louis Andreani, Richard Gloaguen and Klaus P. Stanek wrote the manuscript.

\section{Conflicts of Interest}

The authors declare no conflict of interest.

\section{References}

1. Snyder, N.P.; Whipple, K.X.; Tucker, G.E.; Merritts, D.J. Landscape response to tectonic forcing: Digital elevation model analysis of stream profiles in the Mendocino triple junction region, northern California. Geol. Soc. Am. Bull. 2000, 112, 1250-1263.

2. Burbank, D.W.; Anderson, R.S. Tectonic Geomorphology; Blackwell Science: Oxford, UK, 2001; pp. 1-287.

3. Mather, A.E. Adjustment of a drainage network to capture induced base-level change. Geomorphology 2000, 34, 271-289.

4. Mather, A.E.; Harvey, A.M.; Stokes, M. Quantifying long-term catchment changes of alluvial fan systems. Geol. Soc. Am. Bull. 2000, 112, 1825-1833.

5. Keller, E.A.; Pinter, N. Active Tectonics : Earthquakes, Uplift, and Landscape; Prentice Hall: Upper Saddle River, NJ, USA, 1996.

6. Pérez-Peña, J.V.; Azañón, J.M.; Azor, A. CalHypso: An ArcGIS extension to calculate hypsometric curves and their statistical moments. Applications to drainage basin analysis in SE Spain. Comput. Geosci. 2009, 35, 1214-1223.

7. Schwanghart, W.; Kuhn, N.J. TopoToolbox: A set of Matlab functions for topographic analysis. Environ. Modelli. Softw. 2010, 25, 770-781.

8. Shahzad, F.; Gloaguen, R. TecDEM: A MATLAB based toolbox for tectonic geomorphology, Part 1: Drainage network preprocessing and stream profile analysis. Comput. Geosci. 2011, 37, 250-260.

9. Shahzad, F.; Gloaguen, R. TecDEM: A MATLAB based toolbox for tectonic geomorphology, Part 2: Surface dynamics and basin analysis. Comput. Geosci. 2011, 37, 261-271. 
10. Schwanghart, W.; Scherler, D. Short Communication: TopoToolbox 2-MATLAB-based software for topographic analysis and modeling in Earth surface sciences. Earth Surf. Dyn. 2014, 2, 1-7.

11. El Hamdouni, R.; Irigaray, C.; Fernandez, T.; Chacón, J.; Keller, E.A. Assessment of relative active tectonics, southwest border of Sierra Nevada (southern Spain). Geomorphology 2007, 96, 150-173.

12. Pedrera, A.; Pérez-Peña, J.V.; Galindo-Zaldívar, J.; Azañón, J.M.; Azor, A. Testing the sensitivity of geomorphic indices in areas of low-rate active folding (eastern Betic Cordillera, Spain). Geomorphology 2009, 105, 218-231.

13. Pérez-Peña, J.V.; Azor, A.; Azañón, J.M.; Keller, E.A. Active tectonics in the Sierra Nevada (Betic Cordillera, SE Spain): Insights from geomorphic indexes and drainage pattern analysis. Geomorphology 2010, 119, 74-87.

14. Dehbozorgi, M.; Pourkermani, M.; Arian, M.; Matkan, A.A.; Motamedi, H.; Hosseiniasl, A. Quantitative analysis of relative tectonic activity in the Sarvestan area, central Zagros, Iran. Geomorphology 2010, 121, 329-341.

15. Giaconia, F.; Booth-Rea, G.; Martínez-Martínez, J.M.; Azañón, J.M.; Pérez-Peña, J.V.; Pérez-Romero, J.; Villegas, I. Geomorphic evidence of active tectonics in the Sierra Alhamilla (eastern Betics, SE Spain). Geomorphology 2012, 145-146, 90-106.

16. Mahmood, S.A.; Gloaguen, R. Appraisal of active tectonics in Hindu Kush: Insights from DEM derived geomorphic indices and drainage analysis. Geosci. Front. 2012, 3, 407-428.

17. Pike, R.J.; Wilson, S.E. Elevation relief ratio, hypsometric integral, and geomorphic area-altitude analysis. Geol. Soc. Am. Bull. 1971, 82, 1079-1084.

18. Grohmann, C.H. Morphometric analysis in geographic information systems: Applications of free software GRASS and R. Comput. Geosci. 2004, 30, 1055-1067.

19. Grohmann, C.H.; Riccomini, C.; Alves, F.M. SRTM-based morphotectonic analysis of the Pocos de Caldas Alkaline Massif, southeastern Brazil. Comput. Geosci. 2007, 33, 10-19.

20. Pérez-Peña, J.V.; Azañón, J.M.; Booth-Rea, G.; Azor, A.; Delgado, J. Differentiating geology and tectonics using a spatial autocorrelation technique for the hypsometric integral. J. Geophysi. Res.: Earth Surfce 2009, doi:10.1029/2008JF001092.

21. Hack, J.T. Stream profile analysis and stream-gradient index. U.S. Geol. Surv. J. Res. 1973, $30,421-429$.

22. Wobus, C.; Whipple, K.X.; Kirby, E.; Snyder, N.; Johnson, J.; Spyropolou, K.; Crosby, B.; Sheehan, D. Tectonics from topography: Procedures, promises and pitfalls. Geol. Soc. Am. Bull. 2006, 398, 55-74.

23. Kirby, E.; Whipple, K.X. Expression of active tectonics in erosional landscapes. J. Struct. Geol. 2012, 44, 54-75.

24. Strahler, A.N. Hypsometric (area-altitude) analysis of erosional topography. Geol. Soc. Am. Bull. 1952, 63, 1117-1142.

25. Schumm, S.A. Evolution of drainage systems and slopes in badlands at Perth Amboy, New Jersey. Geol. Soc. Am. Bull. 1956, 67, 597-646.

26. Ohmori, H. Changes in the hypsometric curve through mountain building resulting from concurrent tectonics and denudation. Geomorphology 1993, 8, 263-277. 
27. Delcaillau, B.; Deffontaines, B.; Floissac, L.; Angelier, J.; Deramond, J.; Souquet, P.; Chu, H.T.; Lee, J.F. Morphotectonic evidence from lateral propagation of an active frontal fold; Pakuashan anticline, foothills of Taiwan. Geomorphology 1998, 24, 263-290.

28. Chen, Y.C.; Sung, Q.; Cheng, K.Y. Along-strike variations of morphotectonic features in the Western Foothills of Taiwan: Tectonic implications based on stream-gradient and hypsometric analysis. Geomorphology 2003, 56, 109-137.

29. Domínguez-González, L.; Andreani, L.; Stanek, K.P.; Gloaguen, R. Geomorpho-tectonic evolution of the Jamaican restraining bend. Geomorphology 2014, submitted.

30. Font, M.; Amorese, D.; Lagarde, J.L. DEM and GIS analysis of the stream gradient index to evaluate effects of tectonics: The Normandy intraplate area (NW France). Geomorphology 2010, $119,172-180$.

31. Viveen, W.; van Balen, R.T.; Schoorl, J.M.; Veldkamp, A.; Temme, A.J.A.M.; Vidal-Romani, J.R. Assessment of recent tectonic activity on the NW Iberian Atlantic Margin by means of geomorphic indices and field studies of the Lower Miño River terraces. Tectonophysics 2012, 544, 13-30.

32. Popotnig, A.; Tschegg, D.; Decker, K. Morphometric analysis of a reactivated Variscan fault in the southern Bohemian Massif (Budějovice basin, Czech Republic). Geomorphology 2013, 197, 108-122.

33. Jacques, P.D.; Salvador, E.D.; Machado, R.; Grohmann, C.H.; Nummer, A.R. Application of morphometry in neotectonic studies at the eastern edge of the Paraná Basin, Santa Catarina State, Brazil. Geomorphology 2014, 213, 3-23.

34. Walther, H.; Kiesel, Y.; Kurze, M. Exkursionsführer für das Tertiär im nördlichen und nordwestlichen Gebiet der CSSR; Institut für Geologie, Bergakademie Freiberg: Freiberg, Germany, 1978; pp. 1-17.

35. Wetzel, H. Aspect of the faulting tectonical subdivision of the Eastern Erzgebirge. Z. Geol. Wissenschaft. 1982, 10, 635-644.

36. Skamletz, J.; Korn, M.; Forkmann, B.; Göthe, W. A temporary network for seismological monitoring in West-Saxony: First results. Stud. Geophys. Geod. 2000, 44, 142-157.

37. Peterek, A.; Reuther, C.D.; Schunk, R. Neotectonic evolution of the Cheb Basin (Northwestern Bohemia, Czech Republic) and its implications for the late Pliocene to Recent crustal deformation in the western part of the Eger Rift. Z. Geol. Wissenschaft. 2011, 39, 335-365.

38. Fischer, T.; Horálek, J.; Hrubcová, P.; Vavryčuk, V.; Bräuer, K.; Kämpf, H. Intra-continental earthquake swarms in West-Bohemia and Vogtland: A review. Tectonophysics 2014, doi:10.1016/ j.tecto.2013.11.001.

39. Grenerczy, G.; Sella, G.; Stein, S.; Kenyeres, A. Tectonic implications of the GPS velocity field in the northern Adriatic region. Geophys. Res. Lett. 2005, doi:10.1029/2005GL022947.

40. Bus, Z.; Grenerczy, G.; Tóth, L.; Mónus, P. Active crustal deformation in two seismogenic zones of the Pannonian region-GPS versus seismological observations. Tectonophysics 2009, 474, 21-28.

41. Hemmann, A.; Kämpf, H. Seismicity in the central part of the Naab-Pritzwalk-Rostock Lineament, related to mantel fluid activity ? In Proceedings of European Geophysical Society 27th General Assembly, Nice, France, 21-26 April 2002. 
42. Kracke, D.W.; Heinrich, R. Local seismic hazard assessment in areas of weak to moderate seismicity-Case study from Eastern Germany. Tectonophysics 2004, 390, 45-55.

43. Fischer, T.; Horálek, J. Slip-generated patterns of swarm microearthquakes from West Bohemia/Vogtland (central Europe): Evidence of their triggering mechanism. J. Geophys. Res.: Solid Earth 2005, 110, 1-14.

44. Babuška, V.; Plomerová, J.; Fischer, T. Intraplate seismicity in the western Bohemian Massif (central Europe): A possible correlation with a paleoplate junction. J. Geodyn. 2007, 44, 149-159.

45. National Earthquake Information Center-NEIC. Available online: http://earthquake.usgs.gov/ earthquakes/search/ (accessed on 15 August 2014).

46. Bräuer, K.; Kämpf, H.; Strauch, G.; Weise, S.M. Isotopic evidence $\left({ }^{3} \mathrm{He} /{ }^{4} \mathrm{He},{ }^{13} \mathrm{C}_{\mathrm{CO} 2}\right)$ of fluid-triggered intraplate seismicity. J. Geophys. Res. 2003, doi:10.1029/2002JB002077.

47. Weinlich, F.; Bräuer, K.; Kämpf, H.; Strauch, G.; Tesař, J.; Weise, S. Gas Flux and Tectonic Structure in the Western Eger Rift, Karlovy Vary-Oberpfalz and Oberfranken, Bavaria. GeoLines 2003, 15, 181-187.

48. Westaway, R. Long-term river terrace sequences: Evidence for global increases in surface uplift rates in the Late Pliocene and early Middle Pleistocene caused by flow in the lower continental crust induced by surface processes. Neth. J. Geosci. 2002, 81, 305-328.

49. Tyráček, J.; Westaway, R.; Bridgland, D. River terraces of the Vltava and Labe (Elbe) system, Czech Republic, and their implications for the uplift history of the Bohemian Massif. P. Geologist. Assoc. 2004, 115, 101-124.

50. Ziegler, P.A. European Cenozoic rift system. Tectonophysics 1992, 208, 91-111.

51. Dèzes, P.; Schmid, S.M.; Ziegler, P.A. Evolution of the European Cenozoic Rift System: Interaction of the Alpine and Pyrenean orogens with their foreland lithosphere. Tectonophysics 2004, 31, 1-33.

52. Ziegler, P.A.; Dèzes, P. Cenozoic uplift of Variscan Massifs in the Alpine foreland: Timing and controlling mechanisms. Glob. Planet Chang. 2007, 58, 237-269.

53. Hrubcová, P.; Środa, P.; Špičák, A.; Guterch, A.; Grad, M.; Keller, G.R.; Brueckl, E.; Thybo, H. Crustal and uppermost mantle structure of the Bohemian Massif based on CELEBRATION 2000 data. J. Geophys. Res. 2005, doi:10.1029/2004JB003080.

54. Mlčoch, B.; Konopásek, J. Pre-Late Carboniferous geology along the contact of the Saxo-thuringian and Teplá-Barrandian zones in the area covered by younger sediments and volcanics (western Bohemian Massif, Czech Republic). J. Geosci. 2010, 55, 81-94.

55. Hoth, K.; Eilers, H.; Fritzsche, H. Geologische Übersichtskarte des Freistaates Sachsen 1:400,000 (Karte ohne känozoische Sedimente); Sächsisches Landesamt für Umwelt und Geologie, Bereich Boden und Geologie: Dresden, hlSachsen, Germany, 1995.

56. Cháb, J.; Stráník, Z.; Eliáš, M. Geological Map of the Czech Republic at 1:500,000; Czech Geological Survey: Prag, Czech Republic, 2007.

57. Bankwitz, P.; Schneider, G.; Kämpf, H.; Bankwitz, E. Structural characteristics of epicentral areas in Central Europe: Study case Cheb Basin (Czech Republic). J. Geodyn. 2010, 35, 5-23.

58. Peterek, A.; Schröder, B. Neogene fault activity and morphogenesis in the basement area north of the KTB drill site (Fichtelgebirge and Steinwald. Geol. Rundsch. 1997, 86, 185-190. 
59. Cajz, V.; Vokurka, K.; Balogh, K.; Lang, M.; Ulrych, J. The České středohoří Mts.: volcanostratigraphy and geochemistry. GeoLines 1999, 9, 21-28.

60. Adamovic, J.; Coubal, M. Intrusive geometries and Cenozoic stress history of the northern part of the Bohemian Massif. GeoLines 1999, 9, 5-14.

61. Ulrych, J.; Pivec, E.; Lang, M.; Balogh, K.; Kropaček, V. Cenozoic intraplate volcanic rocks series of the Bohemian Massif: A review. GeoLines 1999, 9, 123-129.

62. Malkovský, M. The Mesozoic and Tertiary basins of the Bohemian Massif and their evolution. Tectonophysics 1987, 137, 31-42.

63. Malkovský, M. Palaeogeography of the Miocene of the Bohemian Massif. Vy̌stník Ústředního Ústavu Geologického 1975, 50, 27-31.

64. Teodoridis, V.; Kvaček, Z. Complex palaeobotanical research of deposits overlying the main coal seam (Libkovice and Lom Mbs.) in the Most Basin (Czech Republic). Bull. Geosci. 2006, 81, 93-113.

65. Müller, B.; Wehrle, V.; Zeyen, H.; Fuchs, K. Short-scale variations of tectonic regimes in the western European stress province north of the Alps and Pyrenees. Tectonophysics 1997, 275, 199-219.

66. Jarosinski, M. Recent tectonic stress field investigations in Poland: A state of the art. Geol. Quart. 2006, 50, 303-321.

67. Rajchl, M.; Uličný, D.; Grygar, R.; Mach, K. Evolution of basin architecture in an incipient continental rift: The Cenozoic Most Basin, Eger Graben (Central Europe). Basin Res. 2009, 21, 269-294.

68. Stanek, K.P. Junge (känozoische) tektonische Entwicklung in Kristallingebieten in Sachsen (unpublished report); Sächsisches Landesamt für Umwelt, Landwirtschaft und Geologie: Freiberg, Sachsen, Germany, 2014.

69. Suhr, P. The Bohemian Massif as a catchment area for the NW European Tertiary basin. GeoLines 2003, 15, 147-159.

70. Isacks, B.L. Long term land surface processes: Erosion, tectonics and climate history in mountain belts. In TERRA-1: Understanding the Terrestrial Environment; Mather, P., Ed.; Taylor and Francis: London, UK, 1992; pp. 21-36.

71. Masek, J.G.; Isacks, B.L.; Gubbels, T.L.; Fielding, E.J. Erosion and tectonics at the margins of continental plateaus. J. Geophys. Res.: Solid Earth 1994, doi:10.1029/94JB00461.

72. Duncan, C.; Masek, J.; Fielding, E. How steep are the Himalaya? Characteristics and implications of along-strike topographic variations. Geology 2003, 31, 75-78.

73. Ponza, A.; Pazzaglia, F.J.; Picotti, V. Thrust-fold activity at the mountain front of the Northern Apennines (Italy) from quantitative landscape analysis. Geomorphology 2010, 123, 211-231.

74. Jarvis, A.; Reuter, H.I.; Nelson, A.; Guevara, E. Hole-Filled Seamless SRTM Data V4. Available online: http://srtm.csi.cgiar.org (accessed on 15 August 2014).

75. Cheng, K.Y.; Hung, J.H.; Chang, H.C.; Tsai, H.; Sung, Q.C. Scale independence of basin hypsometry and steady state topography. Geomorphology 2012, 171-172, 1-11.

76. Fairfield, J.; Leymarie, P. Drainage networks from grid digital elevation models. Water Resour. Res. 1991, 27, 709-717. 
77. Jones, R. Algorithms for using a DEM for mapping catchment areas of stream sediment samples. Comput. Geosci. 2002, 28, 1051-1060.

78. Strahler, A.N. Quantitative analysis of watershed geomorphology. Trans. Am. Geophys. Union 1957, 8, 913-920.

79. Kirby, E.; Whipple, K.X. Quantifying differential rock-uplift rates via stream profile analysis. Geology 2001, 29, 415-418.

80. Troiani, F.; Della Seta, M. The use of the Stream Length-Gradient index in morphotectonic analysis of small catchments: A case study from Central Italy. Geomorphology 2008, 102, 159-168.

81. Whittaker, A.C.; Attal, M.; Cowie, P.A.; Tucker, G.E.; Roberts, G. Decoding temporal and spatial patterns of fault uplift using transient river long profiles. Geomorphology 2008, 100, 506-526.

82. Flint, J.J. Stream gradient as a function of order, magnitude and discharge. Water Resour. Res. 1974, 10, 969-973.

83. Schoenbohm, L.M.; Whipple, K.X.; Burchfiel, B.C.; Chen, L. Geomorphic constraints on surface uplift, exhumation, and plateau growth in the Red River region, Yunnan Province, China. Geol. Soc. Am. Bull. 2004, 116, 895-909.

84. Clark, M.K.; Maheo, G.; Saleeby, J.; Farley, K.A. The non-equilibrium landscape of the southern Sierra Nevada, California. GSA Today 2005, 15, 4-10.

85. Gallen, S.F.; Wegmann, K.W.; Bohnenstiehl, D.R. Miocene rejuvenation of topographic relief in the southern Appalachians. GSA Today 2013, doi:10.1130/GSATG163A.1.

86. Hack, J.T. Studies of longitudinal stream profiles in Virginia and Maryland. U.S. Geol. Surv. Prof. Paper 1957, 294, 45-97.

87. Hack, J.T. Interpretation of erosional topography in humid temperate regions. Am. J. Sci. 1960, 258A, 80-97.

88. Willett, S.; Brandon, M. On steady states in mountain belts. Geology 2002, 30, 175-178.

89. Pazzaglia, F.J. Landscape evolution models. In The Quaternary Period in the United States; Gillespie, A.R.; Porter, S.; Atwater, B.F., Eds.; Elsevier Science Ltd.: Oxford, UK, 2003; pp. 247-274.

90. Matmon, A.; Bierman, P.R.; Larsen, J.; Southworth, S.; Pavich, M.; Caffee, M. Temporally and spatially uniform rates of erosion in the southern Appalachian Great Smoky Mountains. Geology 2003, 31, 155-158.

91. Tyráček, J. Upper Cenozoic fluvial history in the Bohemian Massif. Quatern. Int. 2001, 79, $37-53$.

92. Eissmann, L. Quaternary geology of eastern Germany (Saxony, Saxon-Anhalt, South Brandenburg, Thüringia), type area of the Elsterian and Saalian Stages in Europe. Quat. Sci. Rev. 2002, $21,1275-1346$.

93. Staff, H. Die Geomorphogenie und Tektonik des Gebietes der Lausitzer Überschiebung; Geologie und Palontologie Abhandlungen: Jena, Thuringia, Germany, 1914; B13H2, pp. 85-123.

(c) 2014 by the authors; licensee MDPI, Basel, Switzerland. This article is an open access article distributed under the terms and conditions of the Creative Commons Attribution license (http://creativecommons.org/licenses/by/3.0/). 